OPEN ACCESS

Edited by:

Veronica Graciela Maurino,

Heinrich Heine University Düsseldorf,

Germany

Reviewed by:

Gonzalo Martin Estavillo,

Commonwealth Scientific and Industrial Research Organisation (CSIRO), Australia

Wagner L. Araújo,

Universidade Federal de Viçosa, Brazil

*Correspondence:

Jian-Ying Ma

jyma@ms.xjb.ac.cn

Wei Sun

sunwei@nenu.edu.cn

Specialty section:

This article was submitted to

Plant Physiology,

a section of the journal

Frontiers in Plant Science

Received: 15 March 2019 Accepted: 06 June 2019

Published: 03 July 2019

Citation:

Zhong S, Xu Y, Meng B, Loik ME, Ma J-Y and Sun W (2019) Nitrogen

Addition Increases the Sensitivity

of Photosynthesis to Drought and Re-watering Differentially in $C_{3}$

Versus $C_{4}$ Grass Species.

Front. Plant Sci. 10:815

doi: 10.3389/fp/s.2019.00815

\section{Nitrogen Addition Increases the Sensitivity of Photosynthesis to Drought and Re-watering Differentially in $\mathrm{C}_{3}$ Versus $\mathrm{C}_{4}$ Grass Species}

\author{
Shangzhi Zhong ${ }^{1}$, Yueqiao Xu1 ${ }^{1}$, Bo Meng ${ }^{1}$, Michael E. Loik², Jian-Ying Ma ${ }^{* *}$ and \\ Wei Sun ${ }^{1 *}$
}

1 Key Laboratory of Vegetation Ecology, Ministry of Education, Institute of Grassland Science, Northeast Normal University, Changchun, China, ${ }^{2}$ Department of Environmental Studies, University of California, Santa Cruz, Santa Cruz, CA, United States, ${ }^{3}$ Key Laboratory of Biogeography and Bioresources in Arid Land, Xinjiang Institute of Ecology and Geography, Chinese Academy of Sciences, Ürümqi, China

Global change factors, such as variation in precipitation regimes and nitrogen $(\mathrm{N})$ deposition, are likely to occur simultaneously and may have profound impacts on the relative abundance of grasses differing in functional traits, such as $\mathrm{C}_{3}$ and $\mathrm{C}_{4}$ species. We conducted an extreme drought and re-watering experiment to understand differences in the resistance and recovery abilities of $\mathrm{C}_{3}$ and $\mathrm{C}_{4}$ grasses under different $\mathrm{N}$ deposition scenarios. $\mathrm{A}_{3}$ perennial grass (Leymus chinensis) and two $\mathrm{C}_{4}$ grasses (annual species Chloris virgata and perennial species Hemarthria altissima) that cooccur in Northeast China were selected as experimental plants. For both $\mathrm{C}_{3}$ and $\mathrm{C}_{4}$ grasses, $\mathrm{N}$ addition caused a strong increase in biomass and resulted in more severe drought stress, leading to a change in the dominant photosynthetic limitation during the drought periods. Although $\mathrm{N}$ addition increased antioxidant enzyme activities and protective solute concentrations, the carbon fixing capacity did not fully recover to predrought levels by the end of the re-watering period. N addition resulted in lower resilience under the drought conditions and lower resistance at the end of the re-watering. However, $\mathrm{N}$ addition led to faster recovery of photosynthesis, especially in the $\mathrm{C}_{3}$ grass, which indicate that the effect of $\mathrm{N}$ addition on photosynthesis during drought was asymmetric, especially in the plants with different photosynthetic nitrogen use efficiency (PNUE). These findings demonstrated that nitrogen deposition may significant alter the susceptibility of $\mathrm{C}_{3}$ and $\mathrm{C}_{4}$ grass species to drought stress and re-watering, highlighting the asymmetry between resistance and resilience and to improve our understanding about plant responses to climate change.

Keywords: extreme climate, $\mathrm{N}$ deposition, recovery extent and rate asymmetry, resistance, resilience, water pulse 


\section{INTRODUCTION}

Globally, the intensification of the hydrologic cycle (Knapp et al., 2008; Smith, 2011; IPCC, 2013; Knapp et al., 2015) is expected to increase the frequency and magnitude of climate extremes, such as severe drought and intense rainfall (Karl et al., 1995; Hoerling and Kumar, 2003; Reichstein et al., 2013). These extreme climate events are likely to interact with chronic environmental changes, such as N deposition (Liu et al., 2011, 2013; Zhu et al,, 2016), to alter key aspects of ecosystem carbon cycling, such as photosynthetic carbon assimilation (Xia and Wan, 2008; Xu et al., 2013; Wang et al., 2015; Shi et al., 2018). $C_{3}$ and $C_{4}$ plants may respond differently to altered precipitation and $\mathrm{N}$ deposition due to functional differences in anatomical structure, photosynthetic processes, responses to temperature, and water and N use efficiency (Long, 1999; Yuan et al., 2007; Niu et al., 2008a; Ripley et al., 2010; Taylor et al., 2014). Such differences could cause substantial changes in vegetation composition and ecosystem functions (Still et al., 2003).

Plants with the $\mathrm{C}_{4}$ enzyme pathway for concentrating $\mathrm{CO}_{2}$ can reduce stomatal aperture while fixing $\mathrm{CO}_{2}$ at rates equal to or greater than $\mathrm{C}_{3}$ species; thus, $\mathrm{C}_{4}$ species have higher water-use efficiency (WUE) than $C_{3}$ species (Pearcy and Ehleringer, 1984; Taylor et al., 2014). Based on relative performance of $C_{3}$ and $C_{4}$ photosynthesis, $\mathrm{C}_{4}$ species are expected to outperform $\mathrm{C}_{3}$ species in warm habitats and conditions that promote stomatal closure (drought, warm temperatures, high salinity, and low humidity) (Taiz and Zeiger, 1991; Raven et al., 1992; Haxeltine and Prentice, 1996). Some previous studies have reported that $C_{4}$ species can maintain high WUE under drought conditions and thus maintain their photosynthetic advantage over $\mathrm{C}_{3}$ species (Taylor et al., 2014). However, other studies found that leaf carbon assimilation in $\mathrm{C}_{4}$ species is sensitive to variation in soil water content, such that they can sometimes even lose their photosynthetic advantage (Ripley et al., 2007, 2010; Ibrahim et al., 2008; Taylor et al., 2011).

The inhibitory effects of drought on photosynthesis can be associated with low $\mathrm{CO}_{2}$ availability within the stroma of chloroplasts caused by diffusion limitations through the stomata and the mesophyll (Flexas et al., 2004), the alteration of enzymatic carbon assimilation (Lawlor, 2002; Lawlor and Cornic, 2002), and phloem transport limitations (Mencuccini and Hölttä, 2010). Stomatal closure is an early response to drought and an efficient way to reduce water loss when drought is not too severe; however, it limits $\mathrm{CO}_{2}$ diffusion into the leaves for photosynthesis (Cornic et al., 2000). Changes in mesophyll conductance $\left(g_{\mathrm{m}}\right)$ may also play an important role in the drought-induced reduction of leaf carbon supply for assimilation (Grassi and Magnani, 2005). The sum of both stomatal and mesophyll limitations represents the diffusional limitations of the key photosynthetic substrate, $\mathrm{CO}_{2}$. Inhibition of metabolic activities occurs with prolonged periods of drought stress (Parry et al., 2002). Biochemical or metabolic (non-stomatal) limitations of photosynthesis under drought stress include reductions in carboxylation efficiency (CE), a decline in the maximum velocity for carboxylation of Rubisco $\left(\mathrm{V}_{\mathrm{cmax}}\right)$, the maximal phosphoenolpyruvate carboxylation rate $\left(\mathrm{V}_{\mathrm{pmax}}\right)$, ribulose-1,5-bisphosphate $(\mathrm{RuBP})$ regeneration capacity mediated by maximum electron rate $\left(J_{\max }\right)$, and decreases in activities of Photosystem II (PSII) and Rubisco (Giardi et al., 1996; Pelloux et al., 2001; Parry et al., 2002; Jia and Gray, 2004; Peña-Rojas et al., 2004; Flexas et al., 2006).

In addition to the rate and degree of photosynthetic decline during soil water depletion, the carbon balance of a plant exposed to water stress may also depend on the rate and degree of photosynthetic recovery after re-watering. Because of the greater magnitude of metabolic limitations in $\mathrm{C}_{4}$ species under severe drought, $\mathrm{C}_{4}$ species are typically more sensitive to drought than $C_{3}$ species, and their recovery from drought is often slower (Ripley et al., 2010). Whereas many studies have addressed different aspects of photosynthetic limitations during drought, analyses of photosynthetic limitations during recovery from water stress are relatively few (Miyashita et al., 2005; Flexas et al., 2006).

Drought resistance and resilience in the context of leaf photosynthesis may be influenced by other factors, such as osmotic adjustment ability, antioxidant enzyme activity, other thermal dissipation processes for PSII (e.g., the xanthophyll cycle), and $\mathrm{N}$ availability. These are crucial processes in plant responses to drought (Morgan, 1984; Chaves et al., 2003) and important in the avoidance of oxidative stress (Smirnoff, 1998; Dat et al., 2000; Sharma et al., 2012). $\mathrm{C}_{3}$ and $\mathrm{C}_{4}$ plants may differ in the metabolism of activated oxygen species (Zhang and Kirkham, 1996) and osmotic adjustment ability, which will change the abilities of $\mathrm{C}_{3}$ and $\mathrm{C}_{4}$ species to acclimate to dramatic variation in water conditions.

Using a pot experiment, we subjected a controlled drought to one $\mathrm{C}_{3}$ (Leymus chinensis) and two $\mathrm{C}_{4}$ (Chloris virgata and Hemarthria altissima) grass species that co-occur widely in the meadow steppe of Northeast China, followed by a re-watering treatment under both fertilized and unfertilized conditions. To assess differences in drought resistance and resilience between the $\mathrm{C}_{3}$ and $\mathrm{C}_{4}$ grasses, and the effects of $\mathrm{N}$ supply on these traits, we measured soil moisture, leaf water potential, leaf-level photosynthetic gas exchange parameters, $\mathrm{CO}_{2}$ dose-response $\left(A-C_{i}\right)$ curves, chlorophyll fluorescence, leaf antioxidant enzyme activity, and protective solute concentrations during the drought and re-watering periods. We hypothesized that (1) the $\mathrm{C}_{4}$ grasses would lose their advantages in WUE, relative to the $C_{3}$ grass, under drought conditions; (2) stomatal limitation plays a more important role for drought impacts on leaf carbon assimilation in $\mathrm{C}_{3}$ grass than in $\mathrm{C}_{4}$ grasses; therefore, the $\mathrm{C}_{3}$ grass would recover more quickly than the $\mathrm{C}_{4}$ grasses after rehydration; and (3) compared to the $\mathrm{C}_{4}$ grasses, the $\mathrm{C}_{3}$ grass would likely benefit, in terms of drought resistance and resilience, from increased $\mathrm{N}$ supply, due to the differences in photosynthetic nitrogen use efficiency (PNUE) between $\mathrm{C}_{3}$ and $\mathrm{C}_{4}$ species.

\section{MATERIALS AND METHODS}

\section{Study Site and Experimental Design}

The experiment was conducted in an open greenhouse at the Grassland Ecological Research Station of the Northeast Normal University, China $\left(44^{\circ} 32^{\prime} \mathrm{N}, 123^{\circ} 40^{\prime} \mathrm{E}, 138-167\right.$ masl). The research area has a semi-arid, continental climate with a 
mean annual temperature of $6.3^{\circ} \mathrm{C}(1950-2014)$ and annual precipitation ranges from 280 to $644 \mathrm{~mm}(1950-2014)$ with over $70 \%$ of the precipitation occurring from June to August (Zhong et al., 2017). Potential evapotranspiration is approximately three times that of the annual precipitation (Qu and Guo, 2003). Vegetation is dominated by L. chinensis (Poaceae) (Trin.) Tzvel. a $\mathrm{C}_{3}$ perennial rhizomatous grass; Phragmites australis, C. virgata, and H. altissima are also abundant (Wang et al., 2018). The soil is classified as chernozem, with soil organic carbon content of $2.0 \%$ and soil total nitrogen content of $0.15 \%$ (Wang et al., 2015).

One $\mathrm{C}_{3}$ perennial grass (L. chinensis) and two $\mathrm{C}_{4}$ grasses [C. virgata (Poaceae) Sw., an annual, and H. altissima (Poaceae) (Poir.) Stapf \& C.E. Hubbard, a perennial] that co-occur in the Songnen meadow steppe were selected as experimental species. On 15th May, 2015, seedlings of L. chinensis and H. altissima were transplanted into plastic pots $(23.5 \mathrm{~cm}$ in diameter and $20 \mathrm{~cm}$ in height) filled with chernozem soil $\left(8 \mathrm{~kg}\right.$ soil pot $\left.{ }^{-1}\right)$. For C. virgata, plants were germinated from seeds on 1st May and transplanted into the plastic pots on 15th May. In order to have enough leaves to do all the destructive sampling, all species were planted with five individuals per pot in monoculture. For soil nitrogen, there were unfertilized (N0) and fertilized (N10) treatments, applied in a completely randomized design. For the fertilized treatment, $\mathrm{NH}_{4} \mathrm{NO}_{3}$ and granular urea (inorganic nitrogen:organic nitrogen $=7: 3$ ) were added to each pot at a rate of $10 \mathrm{~g} \mathrm{~N} \mathrm{~m}^{-2} \mathrm{y}^{-1}$. Other macro- and micro-nutrients (P, K, $\mathrm{S}, \mathrm{Zn}, \mathrm{Cu}, \mathrm{Mn}, \mathrm{Mo}, \mathrm{B}$, and $\mathrm{Fe}$ ) were applied for all treatments to ensure that plant growth was not limited by nutrients other than N. Before the initiation of the drought treatment, all the transplanted plants were placed outside of the greenhouse and well-watered to ensure that plant growth was not limited by water. During the drought treatment (14th -20 th July), all the pots were placed under a transparent plastic shed to exclude natural precipitation. All the pots were watered to $70 \%$ of field capacity during the re-watering period (21st - 27th July). The measurements of leaf gas exchange and the collection of fresh leaf materials were conducted on 14th July (Day 1), 16th July (Day 3), 18th July (Day 5), 20th July (Day 7), and 27th July (Day 14). Timeline figure indicating the dates, age of plants and treatment is provided as Supplementary Information (Supplementary Figure 1). On the aforementioned sampling dates, mature leaves were sampled between 0900 and $1100 \mathrm{~h}$ for the determination of antioxidant enzyme activity, proline, soluble sugar, and starch content. The collected leaves were immediately flash frozen in liquid nitrogen and temporarily stored in a deep freezer $\left(-80^{\circ} \mathrm{C}\right)$.

\section{Meteorological Data and Soil Water Content}

Air temperature, photosynthetic photon flux density (PPFD), relative humidity, and vapor pressure deficit were obtained from an eddy flux tower approximately $2 \mathrm{~km}$ away from the experimental site. Volumetric soil water content (SWC-V) at $0-10 \mathrm{~cm}$ soil depth was measured using a time-domain reflectometry (TDR; TRIME-PICO32) probe (IMKO, Ettlingen, Germany) with single measurement mode and recorded by HD2 Hand-Measurement Device at three points in each pot.

\section{Leaf Gas Exchange}

Leaf gas exchange parameters, including net $\mathrm{CO}_{2}$ assimilation rate $(A)$, transpiration rate $(E)$ and stomatal conductance to water vapor $\left(g_{\mathrm{s}}\right)$, were measured on Day $1,3,5$, and 7 during the drought period and Day 14 during the re-watering period, using an LI-6400 portable photosynthesis system (Li-Cor Biosciences, Lincoln, NE, United States). For each species, leaf photosynthesis measurements were conducted between 0900 and $1100 \mathrm{~h}$ on both unfertilized and fertilized plants (six replicates). In each pot, two of the upper-most fully expanded leaves (the 2nd or 3rd leaf from the top) were used for leaf gas exchange measurements. Inside of the leaf chamber, PPFD was set at $2000 \mu \mathrm{mol} \mathrm{m}{ }^{-2}$ $\mathrm{s}^{-1}$, air temperature at $25^{\circ} \mathrm{C}$ and $\mathrm{CO}_{2}$ concentration at $400 \mathrm{ppm}$. As gas exchange rates change linearly along the length of the leaf, measuring at the center of the leaf provides an estimate of the integrated whole-leaf gas exchange rate. Leaf level intrinsic WUE $\left(A / g_{s}\right)$ and instantaneous WUE $(A / E)$ were calculated as the ratio of net $\mathrm{CO}_{2}$ assimilation rate to stomatal conductance and transpiration rate, respectively.

The resistance and resilience of photosynthetic capacity were calculated as the percent loss of $A(P L A)$ and the percent recovery of $A(P R A)$, respectively:

$P L A(\%)=\left(\frac{A_{\mathrm{i}}-A_{\mathrm{d}}}{A_{\mathrm{i}}}\right) \times 100 \%$ and $\operatorname{PRA}(\%)=\left(\frac{A_{\mathrm{r}}}{A_{\mathrm{i}}}\right) \times 100 \%$

where $A_{\mathrm{i}}, A_{\mathrm{d}}$, and $A_{\mathrm{r}}$ represent $A$ at the initial period of the drought treatment, the end of the drought treatment, and after the re-watering treatment, respectively.

The capacity for photosynthetic recovery (recovery rate of $A$ ) was calculated as:

$$
\text { Recovery rate of } A=\frac{A_{\mathrm{r}}-A_{\mathrm{d}}}{D_{\mathrm{r}}}
$$

where $A_{\mathrm{r}}$ and $A_{\mathrm{d}}$ represent $A$ at the end of the re-watering treatment and at the end of the drought treatment, respectively, and $D_{\mathrm{r}}$ represents the length (days) of the re-watering treatment.

A leaf chamber fluorometer (Model Li-6400-40) was used to determine the chlorophyll fluorescence parameter $F_{\mathrm{V}} / F_{\mathrm{M}}$. Leaves comparable to those used for the gas exchange measurements were used for the chlorophyll fluorescence measurements and the measurements were performed before dawn to ensure full reduction of Photosystem II. A measuring light of about $0.5 \mu \mathrm{mol}$ photon $\mathrm{m}^{-2} \mathrm{~s}^{-1}$ was set at a frequency of $600 \mathrm{~Hz}$ to determine the background fluorescence signal $\left(F_{\mathrm{o}}\right)$. Then, a saturating flash of about $10000 \mu \mathrm{mol}$ photon $\mathrm{m}^{-2} \mathrm{~s}^{-1}$ and duration of $0.8 \mathrm{~s}$ was applied for the estimation of the maximum fluorescence $\left(F_{\mathrm{m}}\right)$. Leaf photochemical efficiency (maximum quantum efficiency of Photosystem II) was calculated as: $F_{\mathrm{V}} / F_{\mathrm{M}}=\left(F_{\mathrm{m}}-F_{\mathrm{o}}\right) / F_{\mathrm{m}}$ (Galmés et al., 2007a).

\section{$A / C_{i}$ Curves}

The relationship between $A$ and intercellular $\mathrm{CO}_{2}$ concentration $\left(C_{\mathrm{i}}\right)$ was measured using the LI-6400 portable photosynthesis system over a range of external $\mathrm{CO}_{2}$ concentrations $\left(C_{\mathrm{a}}\right)$ from 50 to $2000 \mu \mathrm{mol} \mathrm{mol}^{-1}$ (in the order 400, 300, 200, 150, 100, 80, 60, $400,400,600,800,1000,1500$, and $2000 \mu \mathrm{mol} \mathrm{mol}^{-1}$ ) on days 1 , 
$3,5,7$, and 14 of the drought/re-watering period. For each species, four pots were used for $A / C_{\mathrm{i}}$ curve measurements. For each pot, first non-apical and fully expanded leaves were measured for the carbon fixation capacity measurements. Leaf chamber environmental conditions included PPFD $=2000 \mu \mathrm{mol} \mathrm{m}^{-2} \mathrm{~s}^{-1}$, leaf temperature $=25^{\circ} \mathrm{C}$, and vapor pressure deficit $=$ approx. $1.3 \mathrm{kPa}$. For the $\mathrm{C}_{3}$ grass, $\mathrm{CO}_{2}$ response curves were analyzed using the models of Von Caemmerer (2000) and temperature corrections were performed using the equations from Bernacchi et al. (2001) and Bernacchi et al. (2003). For the $\mathrm{C}_{4}$ grasses, $A / C_{\mathrm{i}}$ curves were modeled according to Collatz et al. (1992). Custom made macros were built in Microsoft Office Excel and used to estimate parameters from the $A / C_{\mathrm{i}}$ curves.

\section{Photosynthetic Limitation}

The drought-induced reduction in $A$ (relative to the average value for well-watered plants) was attributed to relative stomatal limitation $\left(\mathrm{R}_{\mathrm{SL}}\right)$ and relative metabolic limitation $\left(\mathrm{R}_{\mathrm{ML}}\right)$, which were modified from the models proposed by Ripley et al. (2010):

$$
\begin{aligned}
\mathrm{R}_{\mathrm{SL}} & =\left(\frac{A_{\mathrm{Ci}, \mathrm{x}}-A_{\mathrm{Ca}, \mathrm{x}}}{A_{\mathrm{Ca}, \text { day } 1}}\right) \times 100 \text { and } \\
\mathrm{R}_{\mathrm{ML}} & =\left(\frac{A_{\mathrm{Ca}, \text { day } 1}-A_{\mathrm{Ci}, \mathrm{x}}}{A_{\mathrm{Ca}, \text { day } 1}}\right) \times 100
\end{aligned}
$$

where $A_{\mathrm{Ci}, \mathrm{x}}$ are the net carbon assimilation rates at an intercellular $\mathrm{CO}_{2}$ concentration of $400 \mathrm{ppm}$ (assuming no stomatal limitation) and $A_{\mathrm{Ca}, \mathrm{x}}$ are the net carbon assimilation rates at an atmospheric $\mathrm{CO}_{2}$ concentration of $400 \mathrm{ppm}$ on days $x=1,5$, and 7 of drought/re-watering period, respectively; $A_{\mathrm{Ca}}$, dayl is the net carbon assimilation rates at an atmospheric $\mathrm{CO}_{2}$ concentration of $400 \mathrm{ppm}$ on day 1 of the drought/rewatering period. For all studies, the values of $R_{M L}$ on day 1 cannot be calculated.

\section{Mid-Day Water Potential}

On the days of gas exchange measurements, mid-day leaf water potential $\left(\Psi_{\mathrm{md}}\right)$ was measured between 1100 and $1300 \mathrm{~h}$ using a pressure chamber (PMS Instruments, Corvallis, OR, United States). For each species, $\Psi_{\text {md }}$ measurements were repeated six times for each treatment. In each pot, two of the upper-most fully expanded leaves (the 2 nd or 3 rd leaf from the top) were used for $\Psi_{\text {md }}$ measurements.

\section{Determination of Solute Concentrations and Water Relations Parameters}

Proline was quantified by the acid-ninhydrin procedure (Bates et al., 1973). Acid-ninhydrin was prepared by warming $1.25 \mathrm{~g}$ ninhydrin in $30 \mathrm{ml}$ of glacial acetic acid and $20 \mathrm{ml}$ of $6 \mathrm{M}$ phosphoric acid, with agitation, until dissolved. Leaf samples (approximately $0.5 \mathrm{~g}$ ) were homogenized with $3 \%$ sulphosalicylic acid $(10 \mathrm{ml})$ and clarified by centrifugation $(3500 \times g$ for $10 \mathrm{~min})$. The supernatant $(2 \mathrm{ml})$ was mixed with $2 \mathrm{ml}$ of acidninhydrin and glacial acetic acid, the mixture was oven incubated at $100^{\circ} \mathrm{C}$ for $1 \mathrm{~h}$, and the reaction was finished in an ice bath.
The reaction mixture was extracted with toluene $(4 \mathrm{ml})$ and absorbance was read at $520 \mathrm{~nm}$, using toluene for a blank. The proline concentration was determined from a standard curve and calculated on a fresh weight basis. Two replicates were measured for each sample, and their mean values were used for further analysis. Leaf soluble carbohydrates and starch concentration were measured according to the microplate enzymatic method (Zhao et al., 2010).

Leaf osmotic pressure $(\pi)$ was calculated based on the van't Hoff Relation at $25^{\circ} \mathrm{C}$, which was performed using the equations from Loik and Nobel (1991) and Nobel (2001):

$$
\pi=R T \Sigma_{\mathrm{C}_{\mathrm{I}}}
$$

where $R$ is the gas constant $\left(8.314 \mathrm{~J} \mathrm{~mol}^{-1} \mathrm{~K}^{-1}\right), T$ is temperature on the absolute scale and $\mathrm{C}_{\mathrm{I}}$ is concentration of all osmotically active solotes (leaf proline and soluble carbohydrates).

\section{Antioxidant Enzymes}

To assay the activities of catalase (CAT, EC 1.11.1.6), peroxidase (POD, EC 1.11.1.7), and superoxide dismutase (SOD, EC 1.15.1.1), leaf samples (approximately $0.5 \mathrm{~g}$ ) were homogenized in an ice-cold mortar with $6 \mathrm{ml}$ of ice-cold $50 \mathrm{mM}$ sodium phosphate buffer ( $\mathrm{pH}$ 7.0) containing $0.2 \mathrm{mM}$ EDTA and $1 \%(\mathrm{w} / \mathrm{v})$ polyvinylpyrrolidone (PVP). The homogenates were filtered and centrifuged at $4^{\circ} \mathrm{C}$ for $20 \mathrm{~min}$ at $15000 \times g$. The supernatant was collected and used for the assays of enzymatic activities (Zhang and Kirkham, 1996). Total SOD activity was determined by measuring its ability to inhibit the photochemical reduction of nitroblue tetrazolium (NBT), according to the method of Giannopolitis and Ries (1977) with some modifications (Chowdhury and Choudhuri, 1985; Zhang and Kirkham, 1996). Activities of CAT and POD were measured by the method of Chance and Maehly (1955). For CAT, the decomposition of $\mathrm{H}_{2} \mathrm{O}_{2}$ was monitored by a decline in absorbance at $240 \mathrm{~nm}\left[\varepsilon=39.4 \mathrm{M}^{-1} \mathrm{~cm}^{-1}\right.$ Nelson and Kiesow (1972)] for $1 \mathrm{~min}$. The reaction was initiated with the addition of enzyme extract $(0.1 \mathrm{ml})$ to a $3 \mathrm{ml}$ reaction mixture containing $50 \mathrm{mM}$ phosphate buffer ( $\mathrm{pH} 7.0$ ) and $15 \mathrm{mM} \mathrm{H}_{2} \mathrm{O}_{2}$. For POD, the oxidation of guaiacol was measured by the increase in absorbance at $470 \mathrm{~nm}\left[\varepsilon=26.6 \mathrm{~m} \mathrm{M}^{-1} \mathrm{~cm}^{-1}\right.$, Chance and Maehly (1955)] for $1 \mathrm{~min}$. The assay contained $50 \mu \mathrm{l}$ of $20 \mathrm{mM}$ guaiacol, $2.83 \mathrm{ml}$ of $10 \mathrm{mM}$ phosphate buffer ( $\mathrm{pH} 7.0$ ), and $0.1 \mathrm{ml}$ of enzyme extract. The reaction was started with the addition of $20 \mu \mathrm{l}$ of $40 \mathrm{mM} \mathrm{H}_{2} \mathrm{O}_{2}$.

The protein contents of crude enzyme extracts were determined according to Bradford (1976) using bovine serum albumin (BSA) as a standard.

\section{Drought Induced Changes}

Drought induced changes in X (e.g., soil water content, leaf midday water potential, and leaf osmotic pressure) was calculated as follows:

$$
\text { Change in } \mathrm{X} \text { during drought }=\mathrm{X}_{\text {day } 7}-\mathrm{X}_{\text {day } 1}
$$




\section{Statistical Analysis}

One-way analysis of variance (ANOVA) was used to assess drought and re-watering effects on $\Psi_{\mathrm{md}}$, volumetric soil water contents, $A, g_{s}, E, A / g_{s}, A / E, P L A, P R A$, recovery rate of $A$, relative stomatal and metabolic limitations of photosynthesis, SOD activity, CAT activity, and POD activity on both nitrogen treatments. $T$-tests were used to detect nitrogen treatment differences for the aforementioned indices. Two-way ANOVA was used to assess the drought/re-watering treatment (D and $\mathrm{R}$, respectively) and nitrogen treatment (N0 vs. N10) effects on the maximum velocity for carboxylation of Rubisco $\left(\mathrm{V}_{\mathrm{cmax}}\right)$ and the maximal phosphoenolpyruvate carboxylation rate $\left(\mathrm{V}_{\mathrm{pmax}}\right)$ in C. virgata and $H$. altissima, $\mathrm{V}_{\mathrm{cmax}}$, and the maximum electron rate $\left(J_{\max }\right)$ in L. chinensis, and on proline, soluble sugar and starch content in all grasses. All analyses were carried out using SPSS software version 22 (SPSS Inc., IL, United States). Average values are reported as the arithmetic mean \pm 1 SE.

\section{RESULTS}

\section{Meteorological Parameters}

For the five measuring dates, there were minimal day-today differences in meteorological parameters, including diurnal mean air temperature, diurnal mean PPFD, diurnal mean relative humidity, and diurnal mean vapor pressure deficit (Supplementary Figure 2).

\section{Soil Water Content and Leaf Water Potential}

Soil water content (SWC) in both $\mathrm{N}$ treatments (N0 and N10) decreased during the drought period (Figures 1A-C). Notably, SWC in the fertilized pots was lower than in the unfertilized pots. Similar patterns were detected for leaf water potential $\left(\Psi_{\mathrm{md}}\right)$ during the drought period, with $\Psi_{\mathrm{md}}$ in the fertilized plants significantly lower than in the unfertilized plants (Figures 1D-F). At the end of the re-watering period, $\Psi_{m d}$ in the unfertilized plants generally recovered to the pre-drought treatment level for all species. However, $\Psi_{\mathrm{md}}$ values in the fertilized plants at the end of the re-watering period were significantly lower than the pre-drought level for all species (Figures 1D-F).

\section{Leaf Gas Exchange During Drought and Re-watering}

For the three grass species, downregulation of net $\mathrm{CO}_{2}$ assimilation $(A)$ occurred during the drought; however, these reductions were mainly apparent on day 5 and day 7 , but not on day 3 (Figures 2A-C). Similar patterns were observed for stomatal conductance $\left(g_{\mathrm{s}}\right)$ and transpiration rate $(E)$ in C. virgara, as well as for $E$ in the fertilized $H$. altissima and L. chinensis plants (Figures 2D-G). For $g_{s}$ in the unfertilized $H$. altissima and $L$. chinensis plants and $E$ in both fertilized and unfertilized $H$. altissima and $L$. chinensis plants, the values increased from day 1 to day 3 and decreased on day 5 and day 7 (Figures 2E,F,H,I). At the initial stage of the drought period (Day 1), there was significant upregulation of $A, g_{s}$, and
$E$ in the fertilized grasses (compared to the unfertilized grasses); whereas the gas exchange parameters in the fertilized grasses were significantly downregulated compared to those of the unfertilized grasses at the end of drought period (Day 7) (Figures 2A-I). For C. virgata and $H$. altissima, there was not much variation in $A / g_{s}$ and $A / E$ detected during the drought period except on day 7 (Figures 2J,K,M,N). The WUE of $L$. chinensis gradually decreased during the drought period (From day 1 to day 7) (Figures 2L,O). For $C$. virgata and $L$. chinensis, there were significant decreases of $A / g_{s}$ and $A / E$ in the fertilized plants by comparison to those in the unfertilized plants (Figures 2J,L,M,O); whereas no $\mathrm{N}$ addition effects on $A / g_{s}$ and $A / E$ were detected for $H$. altissima (Figures 2K,N). At the end of the drought period (Day 7), $A / g_{\mathrm{s}}$ and $A / E$ were lower in the fertilized plants by comparison to the unfertilized plants (Figures 2J-O).

At the end of the re-watering period (Day 14), $A, g_{s}$, and $E$ recovered to some extent for the three grass species for both the fertilized and unfertilized treatments, but the degree of recovery varied (Figures 2A-I). The values of $A$ and $g_{\mathrm{s}}$ in the unfertilized L. chinensis plants recovered to their pre-drought treatment levels (Figures 2C,F). At the end of the re-watering period (Day 14), the values of leaf gas exchange parameters were significantly lower for unfertilized compared to the fertilized H. altissima and L. chinensis plants (Figures 2B,C,E,F,H,I). On the other hand, $A$ and $g_{\mathrm{s}}$ were significantly higher for the unfertilized vs. fertilized C. virgata plants (Figures 2A,D), yet $E$ did not differ between the unfertilized and fertilized plants (Figure 2G). The values of $A / g_{\mathrm{s}}$ and $A / E$ under both the fertilized and unfertilized treatments were mostly restored in $H$. altissima and L. chinensis plants, but not in C. virgata plants (Figures 2J-O). Only $A / g_{s}$ and $A / E$ were significantly lower for the unfertilized compared to the fertilized L. chinensis plants (Figures $\mathbf{2 L}, \mathbf{O}$ ).

\section{Resistance and Resilience of Photosynthesis}

The percentage loss (PLA) and recovery (PRA) of net leaf-level $\mathrm{CO}_{2}$ assimilation $(A)$ were used to assess drought resistance and resilience of photosynthetic capacity, respectively. For all grass species, PLA in the fertilized plants was significantly greater than in the unfertilized plants (Figure 3A). Without fertilization, the $P L A$ of $H$. altissima was significantly lower than in the other two grasses. For fertilized plants, the PLA of C. virgata was significantly higher than the other two species (Figure 3A). During the re-watering period, $L$. chinensis had the highest PRA values; whereas $C$. virgata had the lowest $P R A$ values for both the fertilized and unfertilized treatments (Figure 3B). Without fertilization, $H$. altissima had the highest recovery rate of $A$, followed by $L$. chinensis and C. virgata plants. For fertilized plants, the recovery rates of $A$ in $H$. altissima and $L$. chinensis plants were greater than in C. virgata plants. The $\mathrm{N}$ addition treatment significantly increased the recovery rate of $A$ in H. altissima and L. chinensis, but not in C. virgata plants (Figure 3C).

\section{Maximum Efficiency of Photosystem II}

The values of leaf photochemical efficiency $\left(F_{\mathrm{V}} / F_{\mathrm{M}}\right)$ on day 7 were lower than on day 1 for all grass species for both 


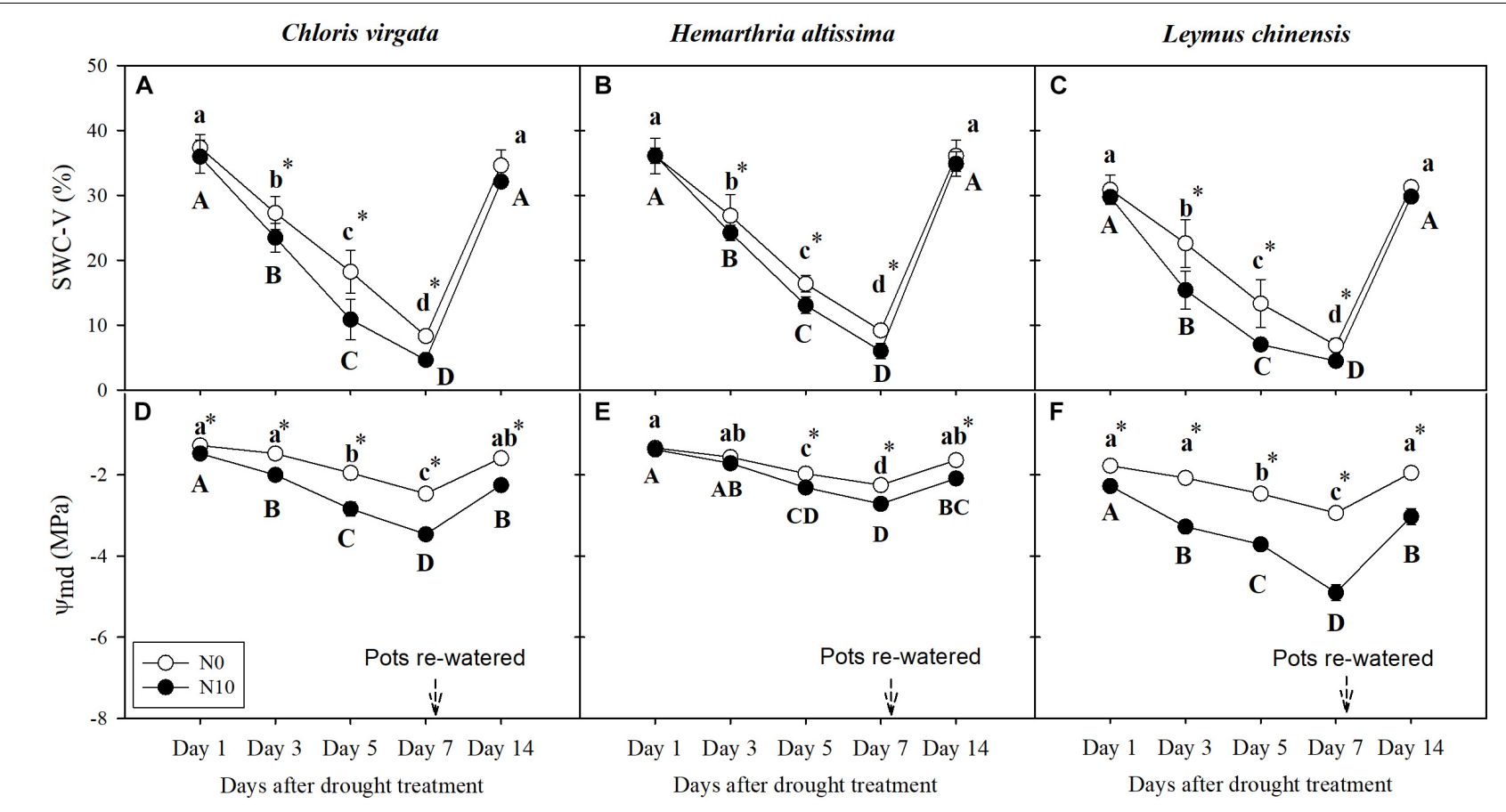

FIGURE 1 | (A-C) Volumetric soil water content (SWC-V, \%) and (D-F) leaf mid-day water potential ( $\Psi_{\mathrm{md}}$; MPa) on days 1, 3, 5, 7, and 14 of the drought/ re-watering treatment in Chloris virgata (annual $\mathrm{C}_{4}$ ), Hemarthria altissima (perennial $\mathrm{C}_{4}$ ), and Leymus chinensis (perennial $\mathrm{C}_{3}$ ). Different lower-case letters and capital letters indicate significant differences between the measuring dates under the unfertilized (N0) treatment and the fertilized (N10) treatment, respectively. "*” represents significant differences between the $\mathrm{N}$ treatments $(P<0.05)$. Data are reported as the arithmetic mean \pm 1 standard error $(n=6)$.

the fertilized and unfertilized treatments. Without fertilization, $F_{\mathrm{V}} / F_{\mathrm{M}}$ decreased from $0.80 \pm 0.005,0.81 \pm 0.002$, and $0.79 \pm 0.003$ on day 1 to $0.61 \pm 0.021,0.68 \pm 0.002$, and $0.71 \pm 0.005$ on day 7 for C. virgata, H. altissima, and L. chinensis, respectively. Moreover, significant downregulation of $F_{\mathrm{V}} / F_{\mathrm{M}}$ in the fertilized grasses was observed by comparison to those in the unfertilized grasses, from $0.79 \pm 0.005,0.82 \pm 0.002$, and $0.83 \pm 0.003$ on day 1 to $0.36 \pm 0.012,0.47 \pm 0.011$, and $0.44 \pm 0.009$ on day 7 for C. virgata, $H$. altissima, and L. chinensis, respectively (Figures $4 \mathbf{A}-\mathbf{C}$ ). At the end of the re-watering period, the $F_{V} / F_{M}$ values for both the $C_{3}$ and $C_{4}$ grasses were significantly lower than their pre-drought levels. For each grass species, considerable upregulation of $F_{\mathrm{V}} / F_{\mathrm{M}}$ in the unfertilized grasses was observed by comparison to those in the fertilized grasses. Comparing unfertilized to fertilized grasses, the $F_{\mathrm{V}} / F_{\mathrm{M}}$ values were $0.69 \pm 0.014$ versus $0.47 \pm 0.011$, $0.79 \pm 0.003$ versus $0.64 \pm 0.006$, and $0.78 \pm 0.007$ versus $0.67 \pm 0.005$ on day 14 for $C$. virgata, $H$. altissima, and L. chinensis, respectively (Figures 4A-C).

\section{Stomatal and Metabolic Limitation of Photosynthesis}

Changes in $A$ as a function of $\mathrm{C}_{\mathrm{i}}$ were used to determine the relative stomatal limitation $\left(\mathrm{R}_{\mathrm{SL}}\right)$ and relative metabolic limitation $\left(\mathrm{R}_{\mathrm{ML}}\right)$ of photosynthesis during the drought treatment (Figure 5). Compared to the values on day $1, \mathrm{R}_{\mathrm{SL}}$ in C. virgata plants (fertilized and unfertilized) and $H$. altissima plants (unfertilized) decreased with time of drought (Figures 5A,B). However, no drought stress-induced variation in $\mathrm{R}_{\mathrm{SL}}$ was detected for L. chinensis plants and fertilized $H$. altissima plants (Figures 5B,C). With the intensification of drought stress, $\mathrm{R}_{\mathrm{ML}}$ increased for all grass species for both the fertilized and unfertilized treatments (Figures 5D-F). Meanwhile, $\mathrm{R}_{\mathrm{ML}}$ in the fertilized grasses were significantly higher than in the unfertilized grasses (Figures 5D-F). R $\mathrm{RL}_{\mathrm{SL}}$ and $\mathrm{R}_{\mathrm{ML}}$ could not be calculated for the fertilized C. virgata plants on day 7 of the drought treatment due to negative values of $A$ (Figures 5A,D).

The estimated $\mathrm{V}_{\mathrm{cmax}}, \mathrm{V}_{\mathrm{pmax}}$, and $\mathrm{J}_{\max }$ values were significantly lower at the end of the drought treatment than their predrought values (Table 1). We were unable to estimate $V_{c m a x}$ and $\mathrm{V}_{\text {pmax }}$ for the fertilized C. virgata plants on day 7 because the extreme drought stress made it impossible to obtain complete $A / C_{\mathrm{i}}$ curves. During the drought period, significant $\mathrm{N}$ addition effects on $\mathrm{V}_{\text {cmax }}, \mathrm{V}_{\text {pmax }}$, and $\mathrm{J}_{\max }$ were detected in C. virgata and $L$. chinensis, but not for $H$. altissima. For all grass species, $\mathrm{V}_{\mathrm{cmax}}, \mathrm{V}_{\text {pmax }}$, and $\mathrm{J}_{\max }$ in the fertilized grasses were significantly higher at the initial stage of drought (except $H$. altissima) and were significantly lower in the unfertilized grasses at the end of the drought treatment. At the end of the re-watering period, $\mathrm{V}_{\text {cmax }}, \mathrm{V}_{\text {pmax }}$, and $\mathrm{J}_{\max }$ were significantly lower than prior to the onset of the drought treatment, with the exception of the unfertilized L. chinensis plants. The parameters were significantly influenced by $\mathrm{N}$ addition in $C$. virgata and L. chinensis, but not in $H$. altissima. The values of $\mathrm{V}_{\mathrm{cmax}}$ and $\mathrm{J}_{\max }$ in the fertilized L. chinensis plants were significantly higher than in the 


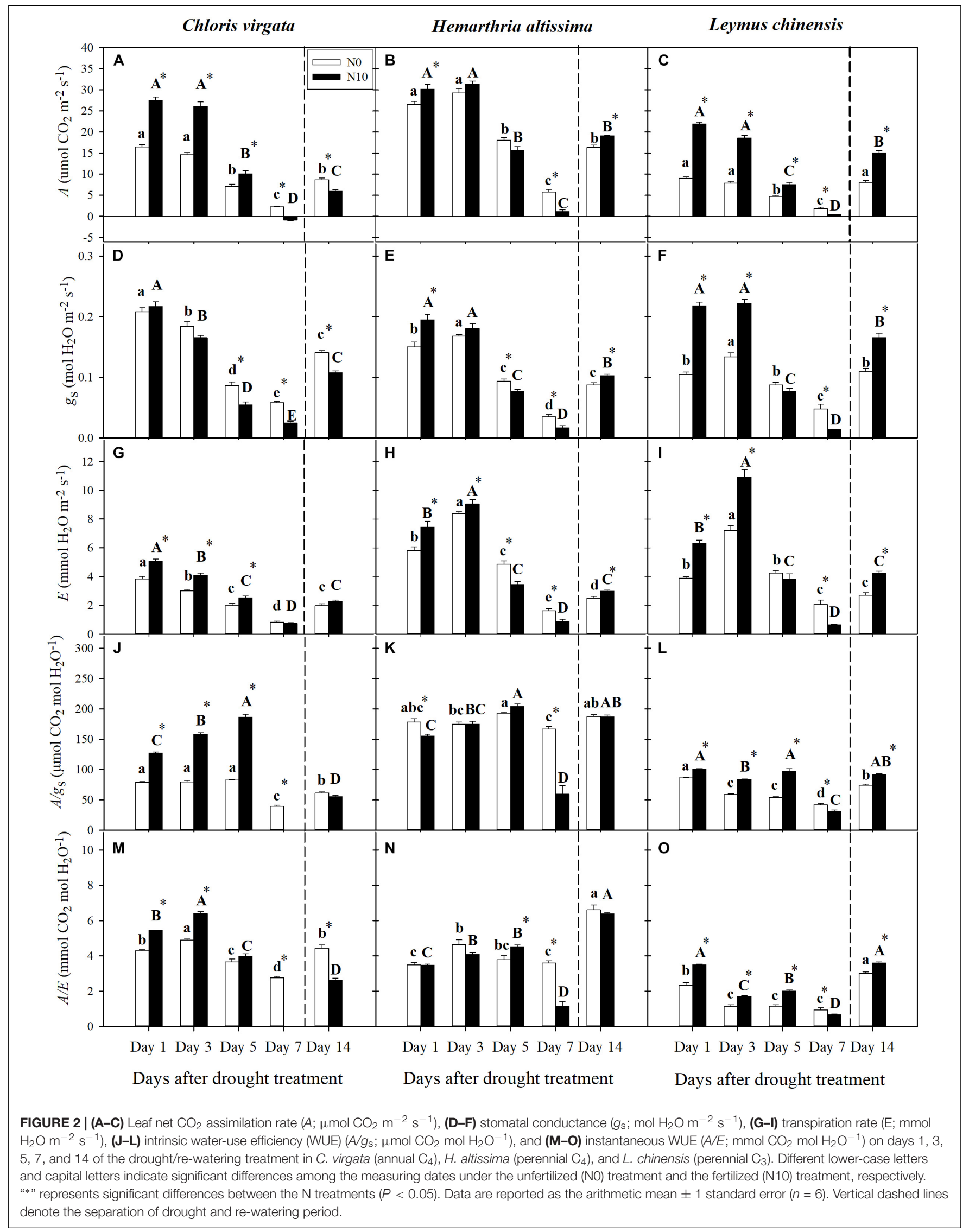




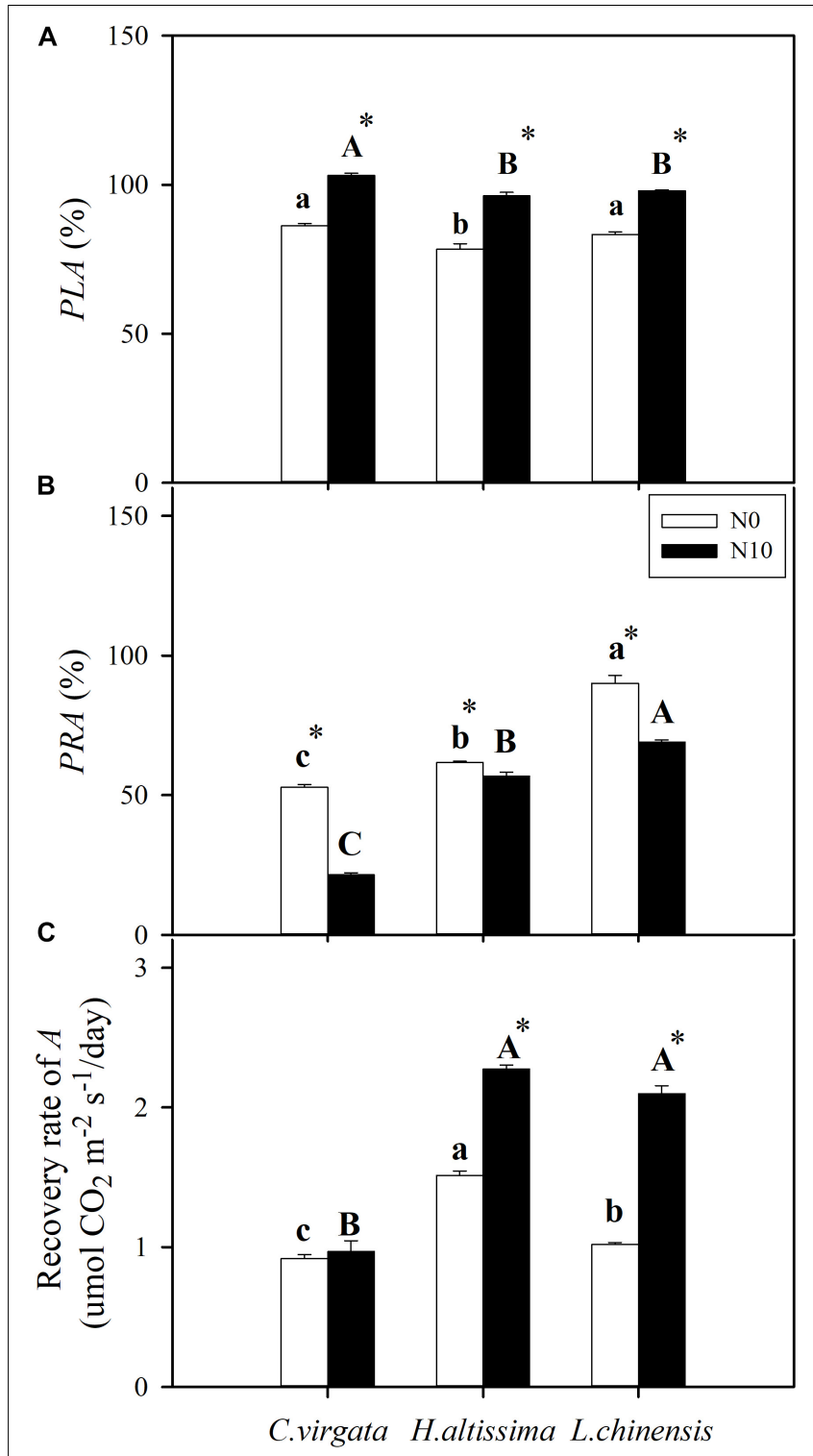

FIGURE 3 | (A) Percentage loss of net $\mathrm{CO}_{2}$ assimilation rate $(P L A),(\mathbf{B})$ percentage recovery of net $\mathrm{CO}_{2}$ assimilation rate $(P R A)$, and $(\mathbf{C})$ the recovery capability (recovery rate of $A$ ) in $C$. virgata (annual $C_{4}$ ), H. altissima (perennial $\mathrm{C}_{4}$ ), and $L$. chinensis (perennial $\mathrm{C}_{3}$ ). Different lower-case letters and capital letters indicate significant differences among the studied grasses under the unfertilized (N0) treatment and the fertilized (N10) treatment, respectively. "** represents significant differences between the $\mathrm{N}$ treatments $(P<0.05)$. Data are reported as the arithmetic mean \pm 1 standard error $(n=6)$.

unfertilized L. chinensis plants; however, $\mathrm{V}_{\mathrm{cmax}}$ and $\mathrm{V}_{\mathrm{pmax}}$ in C. virgata plants under $\mathrm{N}$ addition were lower than in the absence of $\mathrm{N}$ addition (Table $\mathbf{1}$ ).

\section{Solute Concentrations and Water Relations Parameters}

Leaf proline content increased during drought for all species. The $\mathrm{N}$ addition strongly upregulated proline content (Table 2). Leaf soluble sugar content increased in the $\mathrm{C}_{4}$ grasses with the

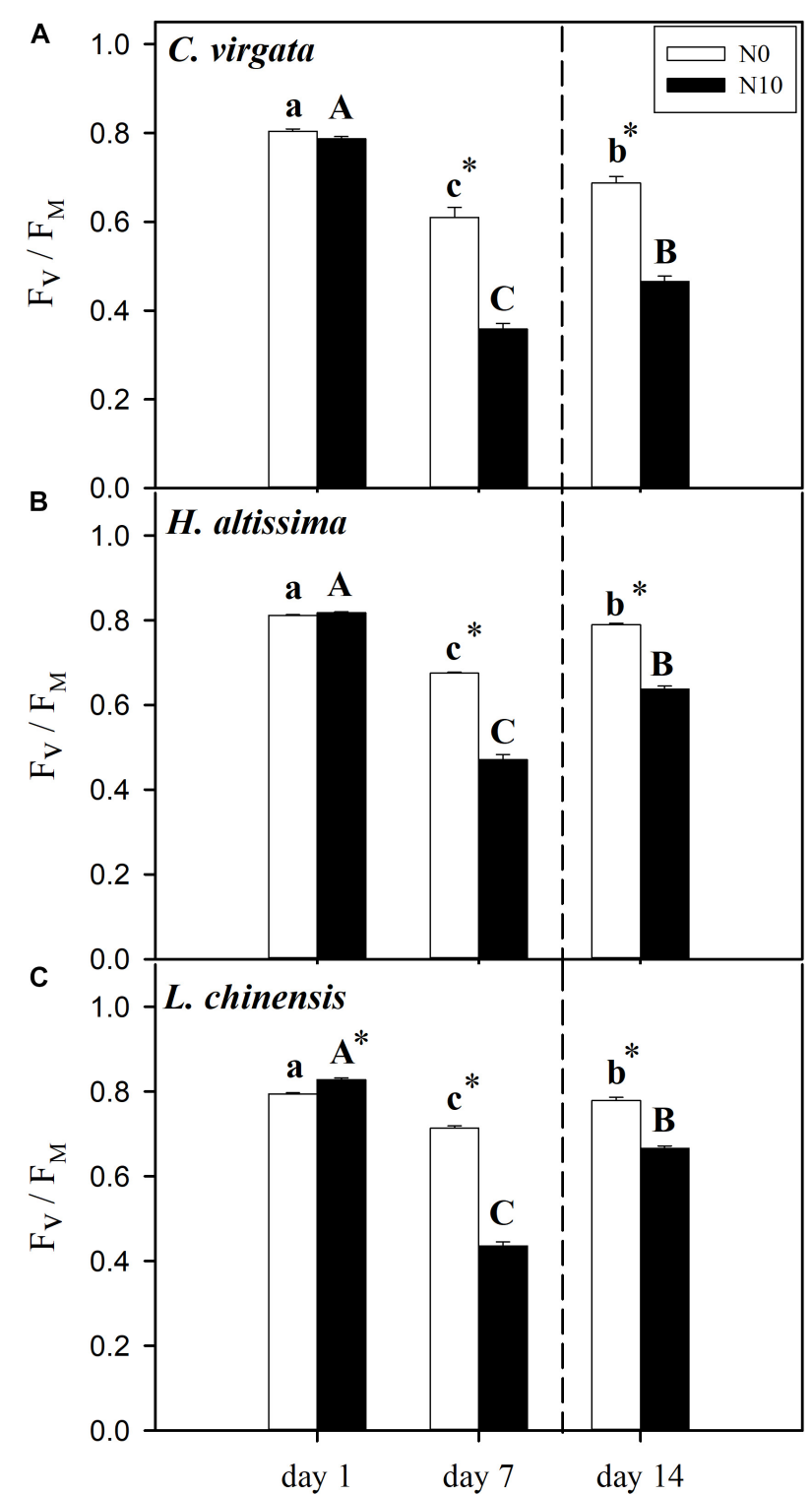

FIGURE 4 | Leaf photochemical efficiency (maximum quantum efficiency of Photosystem II, $F_{\mathrm{V}} / F_{\mathrm{M}}$ ) in (A) C. virgata (annual $\mathrm{C}_{4}$ ), (B) $\mathrm{H}$. altissima (perennia $\mathrm{C}_{4}$ ), and $(\mathbf{C}) L$. chinensis (perennial $\mathrm{C}_{3}$ ) on days 1,7 , and 14 of the drought/re-watering treatment. Different lower-case letters and capital letters indicate significant differences among the measuring dates under the unfertilized (N0) treatment and the fertilized (N10) treatment, respectively. "**" represents significant differences between the $\mathrm{N}$ treatments $(P<0.05)$. Data are reported as the arithmetic mean \pm 1 standard error $(n=6)$. Vertical dashed lines denote the separation of drought and re-watering period.

intensification of drought stress, whereas it decreased in the $\mathrm{C}_{3}$ grass. Leaf starch content gradually decreased from day 1 to day 7 (Table 2). Except for leaf starch content in L. chinensis, significant $\mathrm{N}$ addition effects were detected for soluble sugar and starch in all species. At the end of the re-watering period, leaf proline content remained at higher levels than the pre-drought values (Table 2). Compared to the values on day 1 , significant differences were observed in leaf soluble sugar content and leaf starch content 


\section{Chloris virgata}

Hemarthria altissima

Leymus chinensis

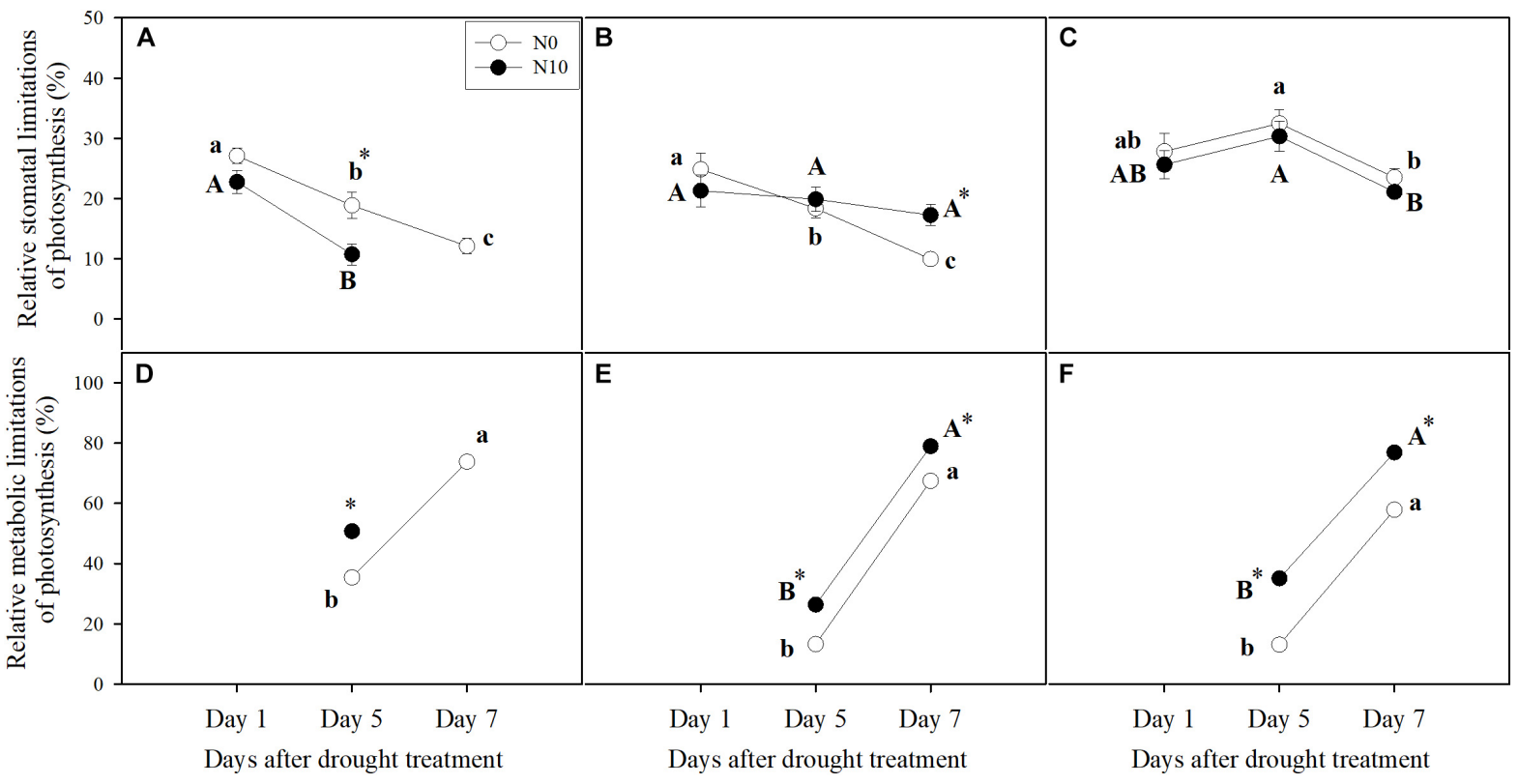

FIGURE 5 | Relative stomatal and metabolic limitations of photosynthesis for (A,D) C. virgata (annual $\mathrm{C}_{4}$ ), (B,E) H. altissima (perennial $\mathrm{C}_{4}$ ), and (C,F) L. chinensis (perennial $C_{3}$ ) on days 1,5 , and 7 of the drought treatment. Different lower-case letters and capital letters indicate significant differences among the measuring dates under the unfertilized (NO) treatment and the fertilized (N10) treatment, respectively. "** represents significant differences between the different N addition treatments $(P<0.05)$. Data are reported as the arithmetic mean \pm 1 standard error $(n=4)$.

TABLE 1 | Effects of the drought/re-watering treatment on maximum Rubisco capacity $\left(\mathrm{V}_{\mathrm{cmax}}\right)$, maximum PEP carboxylation rate ( $\left.\mathrm{V}_{\text {pmax }}\right)$, and maximum rate of photosynthetic electron transport $\left(\mathrm{J}_{\max }\right.$ ) in Chloris virgata (annual $\mathrm{C}_{4}$ ), Hemarthria altissima (perennial $\mathrm{C}_{4}$ ), and Leymus chinensis (perennial $\mathrm{C}_{3}$ ) under both unfertilized (N0) and fertilized (N10) conditions.

\begin{tabular}{|c|c|c|c|c|c|c|c|c|c|c|c|c|}
\hline \multirow[t]{2}{*}{ Species } & & & \multicolumn{3}{|c|}{ Drought } & \multirow{2}{*}{$\frac{\text { Re-watering }}{\text { Day } 14}$} & \multicolumn{3}{|c|}{ Significance (D) } & \multicolumn{3}{|c|}{ Significance (R) } \\
\hline & & & Day 1 & Day 5 & Day 7 & & D & $\mathbf{N}$ & $\mathbf{D} \times \mathbf{N}$ & $\mathbf{R}$ & $\mathbf{N}$ & $\mathbf{R} \times \mathbf{N}$ \\
\hline \multirow[t]{4}{*}{ Chloris virgata } & $V_{c \max }\left(\mu \mathrm{mol} \mathrm{m} \mathrm{m}^{-2} \mathrm{~s}^{-1}\right)$ & NO & $23.41 \pm 0.60$ & $21.10 \pm 2.06$ & $7.06 \pm 1.17$ & $16.79 \pm 1.52$ & $* * *$ & $* * *$ & $* * *$ & $* * *$ & $* * *$ & $* * *$ \\
\hline & & N10 & $51.30 \pm 2.33$ & $16.76 \pm 1.80$ & - & $10.82 \pm 1.18$ & & & & & & \\
\hline & $V_{\text {pmax }}\left(\mu \mathrm{mol} \mathrm{m} \mathrm{m}^{-2} \mathrm{~s}^{-1}\right)$ & NO & $24.65 \pm 2.01$ & $10.86 \pm 0.26$ & $8.28 \pm 0.19$ & $20.63 \pm 0.93$ & $* * *$ & $* * *$ & $*$ & $* * *$ & $* * *$ & $* * *$ \\
\hline & & N10 & $28.64 \pm 0.15$ & $17.95 \pm 0.32$ & - & $10.79 \pm 1.44$ & & & & & & \\
\hline \multirow[t]{4}{*}{ Hemarthria altissima } & $V_{c \max }\left(\mu \mathrm{mol} \mathrm{m} \mathrm{m}^{-2} \mathrm{~s}^{-1}\right)$ & NO & $44.51 \pm 0.91$ & $32.91 \pm 2.67$ & $23.77 \pm 2.40$ & $33.43 \pm 0.98$ & $* * *$ & ns & $* *$ & $* * *$ & ns & ns \\
\hline & & N10 & $47.01 \pm 2.85$ & $32.41 \pm 1.73$ & $14.18 \pm 0.94$ & $30.75 \pm 2.39$ & & & & & & \\
\hline & $V_{p \max }\left(\mu \mathrm{mol} \mathrm{m}^{-2} \mathrm{~s}^{-1}\right)$ & NO & $38.99 \pm 3.00$ & $28.49 \pm 2.38$ & $17.20 \pm 2.53$ & $19.60 \pm 2.98$ & $* * *$ & ns & $* * *$ & $* * *$ & $* * *$ & ns \\
\hline & & N10 & $45.71 \pm 2.58$ & $37.82 \pm 2.01$ & $3.97 \pm 1.07$ & $33.44 \pm 0.85$ & & & & & & \\
\hline \multirow[t]{4}{*}{ Leymus chinensis } & $V_{c \max }\left(\mu \mathrm{mol} \mathrm{m}^{-2} \mathrm{~s}^{-1}\right)$ & NO & $63.88 \pm 6.53$ & $55.88 \pm 8.29$ & $21.65 \pm 3.43$ & $66.62 \pm 6.30$ & $* * *$ & $* * *$ & $* * *$ & $* * *$ & $* * *$ & $* * *$ \\
\hline & & N10 & $158.47 \pm 4.91$ & $64.31 \pm 6.91$ & $11.03 \pm 1.25$ & $110.76 \pm 7.39$ & & & & & & \\
\hline & $J_{\max }\left(\mu \mathrm{mol} \mathrm{m} \mathrm{m}^{-2} \mathrm{~s}^{-1}\right)$ & NO & $147.37 \pm 6.25$ & $105.94 \pm 4.41$ & $35.33 \pm 0.30$ & $137.52 \pm 10.86$ & $* * *$ & $* * *$ & $* * *$ & $*$ & $* * *$ & ns \\
\hline & & N10 & $220.40 \pm 12.48$ & $96.62 \pm 5.50$ & $17.47 \pm 1.30$ & $188.67 \pm 15.42$ & & & & & & \\
\hline
\end{tabular}

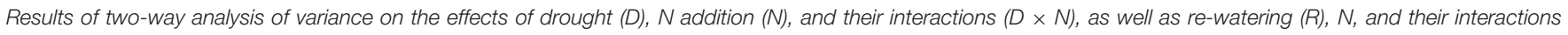

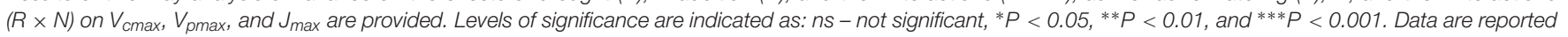
as the arithmetic mean \pm 1 standard error $(n=4)$.

in C. virgata and L. chinensis plants, but not in $H$. altissima plants (Table 2).

Soil water content was reduced by $31 \pm 0.90 \%$ and there was a reduction of midday water potential $\left(\Psi_{\mathrm{md}}\right)$ from $-1.48 \pm 0.07$ to $-3.46 \pm 0.08 \mathrm{MPa}$ for the fertilized pots with $C$. virgata (Figures 1D, 6A). Assuming the plants were in equilibrium with the soil, this corresponds to $30 \%$ of the overall $2 \mathrm{MPa}$ change due to volume reduction, or $0.6 \mathrm{MPa}$. The resulting 1.3 $\mathrm{MPa}$ difference in $\Psi_{\mathrm{md}}$ during drought is likely due to the production of osmotically active compounds, and Figure 6 shows that osmotic pressure $(\pi)$ increased by $114 \pm 3.9 \%$ during drought for the fertilized C. virgata. Using the van't Hoff relation (Nobel, 2001), we note that the change in concentration of proline during drought contributes about $0.026 \mathrm{MPa}$ to the 
TABLE 2 | Effects of the drought/re-watering treatment on leaf proline content $\left(\mu \mathrm{mol} \mathrm{g}^{-1}\right)$, soluble sugar $\left(\mathrm{mg} \mathrm{g}^{-1}\right)$, and starch content ( $\left.\mathrm{mg} \mathrm{g}^{-1}\right)$ in $\mathrm{C}$. virgata (annual $\left.\mathrm{C}_{4}\right)$, H. altissima (perennial $\mathrm{C}_{4}$ ), and L. chinensis (perennial $\mathrm{C}_{3}$ ).

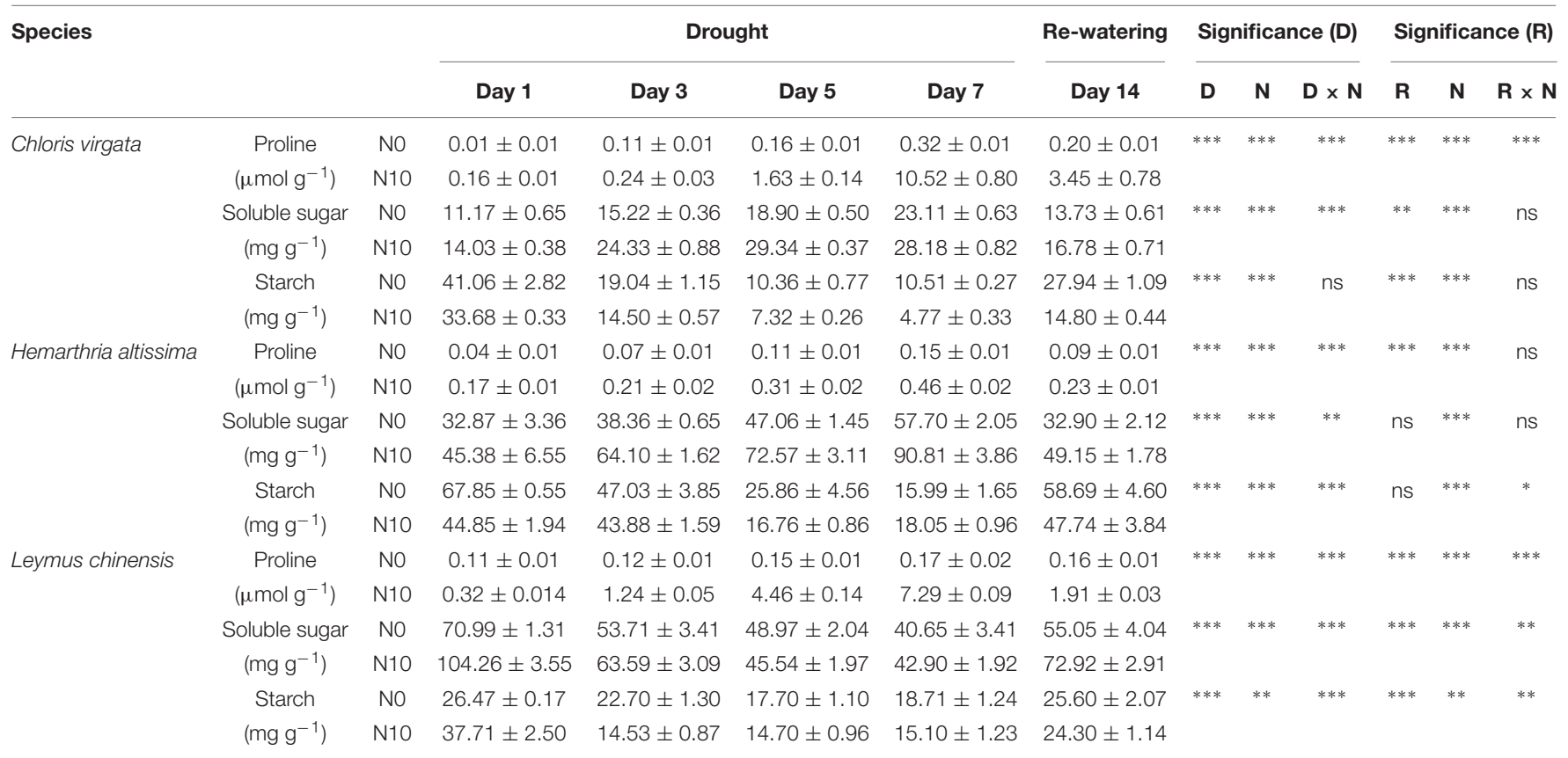

Results of two-way analysis of variance on the effects of drought $(D), N$ addition $(N)$ and their interactions $(D \times N)$, as well as re-watering $(R), N$ and their interactions $(R \times N)$ on the content of proline, soluble sugar and starch are provided. Levels of significance are indicated as: $n s-$ not significant, ${ }^{*} P<0.05,{ }^{* *} P<0.01$, and ${ }^{* * *} P<0.001$. Data are reported as the arithmetic mean \pm 1 standard error $(n=6)$.

overall change in $\Psi$ for the fertilized $C$. virgata, $0.001 \mathrm{MPa}$ for the fertilized H. altissima, and $0.018 \mathrm{MPa}$ for the fertilized L. chinensis. Likewise, the change in sugar concentrations in the unfertilized plants from day 1 to 7 for C. virgata corresponds to $0.39 \pm 0.01 \mathrm{MPa}$, a doubling to $1.25 \pm 0.04 \mathrm{MPa}$ for H. altissima, and a decrease in $\pi$ from $1.43 \pm 0.03$ to $0.59 \pm 0.02 \mathrm{MPa}$ for L. chinensis (Figure 6C).

\section{Antioxidant Enzyme Activities}

With the intensification of drought stress, the antioxidant enzyme activities (SOD, CAT, and POD) were upregulated (Figures 7A-G,I), except for POD in H. altissima (Figure 7H). In general, $\mathrm{N}$-fertilized grasses had the highest antioxidant enzyme activities, especially at the end of the drought period (Figure 7). At the end of the re-watering period, greater SOD activities were detected in all grass species compared to the pre-drought values (Figures 7A-C). For CAT activities, no significant differences were observed between day 14 and day 1 in C. virgata and L. chinensis. Compared to the values on day 1 , significant differences in POD activities were detected only in L. chinensis on day 14 (Figure 7I).

\section{DISCUSSION}

\section{Resistance of Photosynthesis to Water Stress}

Our results demonstrated that a sharp reduction in soil moisture during the drought experiment (Figures 1A-C) and a significant downregulation of photosynthesis for both of the representative $\mathrm{C}_{3}$ and $\mathrm{C}_{4}$ grasses from northeastern China (Figures 2A-C). Consistent with previous studies, stomatal closure was an early response to drought and an effective way to reduce water loss (Figures 2D-I); however, it also limits $\mathrm{CO}_{2}$ diffusion into the leaves, which causes the decrease in $A$ (Cornic et al., 2000). Under drought conditions, plants tend to maintain or increase WUE to cope with water limitation (Ripley et al., 2010). However, this was observed only in the $\mathrm{C}_{4}$ grasses from day 1 to day 5 under the drought treatment (Figures 2J-O). Contrary to our hypothesis, $\mathrm{C}_{4}$ grasses maintained high WUE under drought conditions and thus maintained their photosynthetic advantage relative to $C_{3}$ grasses (Taylor et al., 2014). As drought stress further intensified, the severe reduction in $A$ (Figures $2 \mathrm{~A}-\mathrm{C}$ ) resulted in dramatic declines in $A / g_{s}$ and $A / E$ in both the $\mathrm{C}_{3}$ and $\mathrm{C}_{4}$ grasses (Figures 2J-O). Nitrogen addition increased the $\mathrm{N}$ content of leaves (Supplementary Figure 3) and thus could enhance their photosynthetic capacity, which could further improve WUE in both the $C_{3}$ and $C_{4}$ grasses, but only when the plants were subjected to drought stress from day 1 to day 5 (Figures 2J-O). This is consistent with the results of previous studies (Niu et al., 2005, 2008b). The positive effects of $\mathrm{N}$ addition on WUE disappeared at the end of the drought treatment, which may be attributed to greater biomass (Supplementary Figure 4) and more water consumption by transpiration associated relatively severe drought stress as compared to the unfertilized plants (Figures 1D-F). The results of this study, as well as from many others, suggest that improvement in WUE is an important 


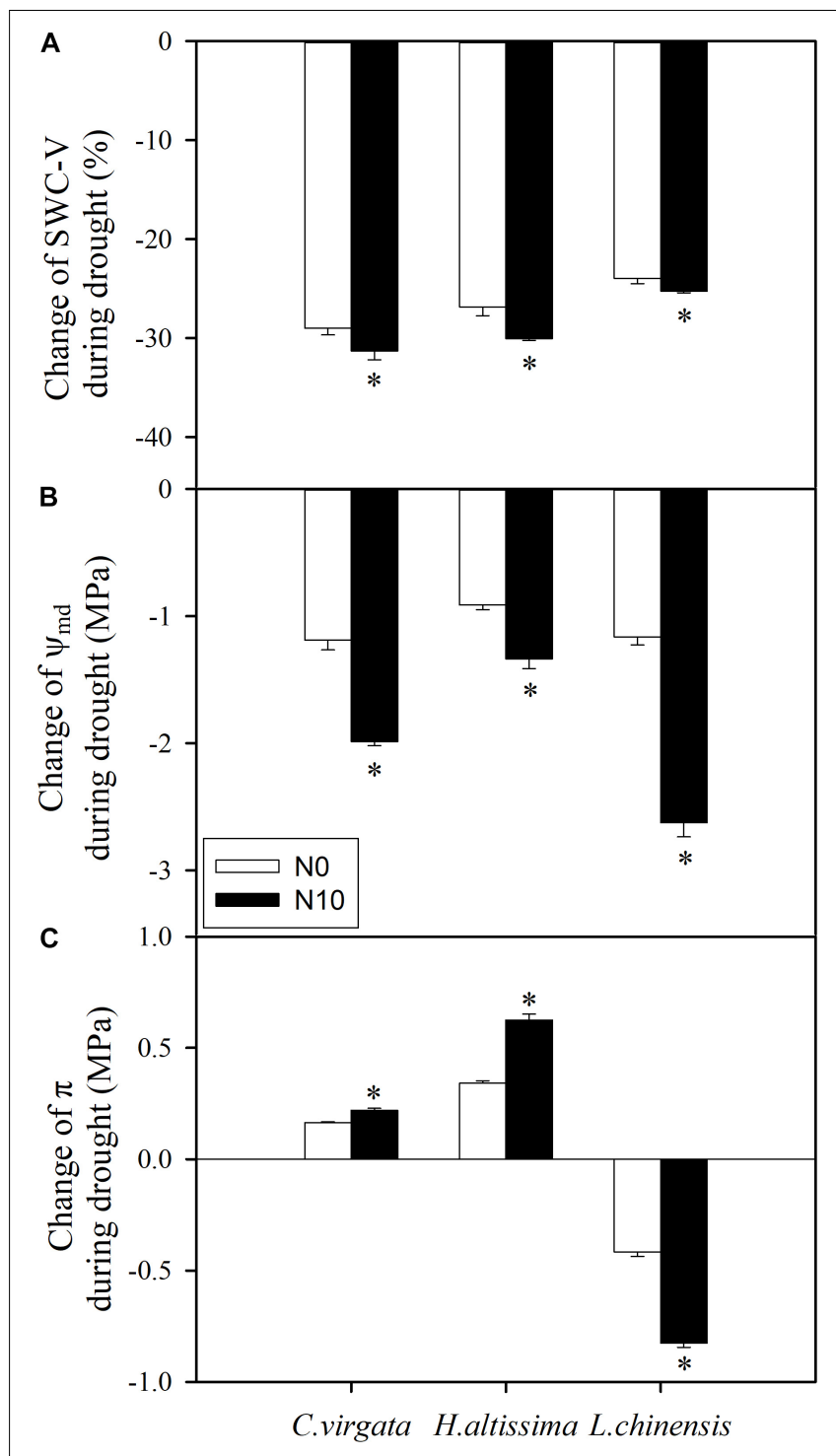

FIGURE 6 | Drought induced changes in (A) soil water content (SWC-V, \%), (B) leaf mid-day water potential $\left(\Psi_{\mathrm{md}} ; \mathrm{MPa}\right)$, and (C) leaf osmotic pressure ( $\pi$; $\mathrm{MPa}$ ) in C. virgata (annual $\mathrm{C}_{4}$ ), H. altissima (perennial $\mathrm{C}_{4}$ ), and L. chinensis (perennial $\mathrm{C}_{3}$ ) under unfertilized (N0) and fertilized (N10) conditions. "*" represents significant differences between the $\mathrm{N}$ treatments $(P<0.05)$. Data are reported as the arithmetic mean \pm 1 standard error.

drought resistance strategy, but it works only under mild drought stress (Ripley et al., 2010).

As has been shown for many $\mathrm{C}_{3}$ and $\mathrm{C}_{4}$ grasses, drought decreased $A$ through a combination of stomatal and metabolic limitations (Lawlor and Cornic, 2002; Ghannoum et al., 2003; Flexas et al., 2006), but the magnitude of these responses differed in these $\mathrm{C}_{3}$ and $\mathrm{C}_{4}$ grasses, and changed as drought progressed (Ripley et al., 2010). In addition, $g_{\mathrm{m}}$ (mesophyll conductance for $\mathrm{CO}_{2}$ diffusion from the intercellular space to the chloroplast stroma) also plays an important role in limiting photosynthesis (Miyashita et al., 2005). With the further intensification of the drought stress over time, stomatal limitations in the $\mathrm{C}_{4}$ grasses
(Figures 5A,B) were lower than stomatal limitations in the $\mathrm{C}_{3}$ grass species (Figure $5 \mathrm{C}$ ). Meanwhile, metabolic limitations were dominant at the end of drought period (Figures 5D-F), which indicates that the nature and timing of photosynthetic downregulation were different among these $\mathrm{C}_{3}$ and $\mathrm{C}_{4}$ grasses. $\mathrm{N}$ addition increased leaf $\mathrm{N}$ content (Supplementary Figure 3), improved the activities of photosynthetic enzymes (Table 1), and reduced stomatal limitations in the fertilized $C$. virgata and L. chinensis plants (Figures 5A,C), which could be attributed to differences in photosynthetic type and life forms. By contrast to the stomatal limitations, there were higher metabolic limitations in the fertilized plants (Figure 5), which may indicate downregulation of Rubisco activity and RuBP regeneration rate due to inadequate ATP or NADPH supply from PSI during water stress (Lawlor, 2002; Parry et al., 2002; Flexas et al., 2004). The decline in photosynthetic capacity $\left(\mathrm{V}_{\text {cmax }}\right.$ and $\left.\mathrm{J}_{\max }\right)$ in the $\mathrm{C}_{3}$ grasses and $\mathrm{V}_{\mathrm{cmax}}$ and $\mathrm{V}_{\text {pmax }}$ in the $\mathrm{C}_{4}$ grasses during drought has been observed in many other grass species (Flexas et al., 2004; Ripley et al., 2010). Therefore, metabolic limitations of photosynthesis in the fertilized grasses (and particularly for the $\mathrm{C}_{3}$ grass) changed with $\mathrm{N}$ addition treatment, which might alter drought recovery after rehydration. $\mathrm{N}$ addition could result in a shift in photosynthetic limitation with the intensified drought stress, resulting in the lower $F_{\mathrm{V}} / F_{\mathrm{M}}$ (Figure 4) and the higher PLA (Figure 3A) in the fertilized plants.

Osmotic solute concentrations and antioxidant enzyme activities have been considered as crucial factors for plant adaptation to drought, because they sustain tissue metabolic activity and reduce progressive oxidative damage resulting from reactive oxygen species, respectively (Morgan, 1984; Zhang and Kirkham, 1996; Chaves et al., 2003). We found a sharp reduction in SWC during the drought treatment (Figures 1A-C) and the percent change in SWC in the fertilized plants was higher than in the unfertilized plants (Figure 6A), which mainly resulted from more plant transpiration caused by more biomass in the fertilized pots (Supplementary Figure 4). The percent change of water potential in the fertilized plants was higher by comparison to those in the unfertilized plants (Figure 6B). For all grass species, as drought stress intensified, there was significant upregulation of proline concentrations in the fertilized compared to unfertilized plants (Table 2), which could improve the stabilization of subcellular structures (Ashraf and Foolad, 2007). Plants also use several sugar-based strategies to tolerate environmental stresses (Anderson and Kohorn, 2001), which can also contribute to changes in osmotic pressure in cells (Nobel, 2001). Soluble sugar content tended to increase in the leaves of droughted plants, despite the decreased rates of carbon assimilation in the $\mathrm{C}_{4}$ grasses (Figures 2A,B). Notably, the proportional decrease in starch content (e.g., by about $75 \%$ from day 1 to 7 for unfertilized C. virgata, Table 2) is greater than the increase for sugars $(c a .2 \times)$, indicating that some of the products of starch hydrolysis were respired or translocated to other tissues. However, this was not observed in the $\mathrm{C}_{3}$ grass L. chinensis, for which both sugar and starch decreased (Chaves, 1991) between day 1 and 7 of drought (Table 2). These results are consistent with our previous study of drought impacts on dark respiration in these three species, 


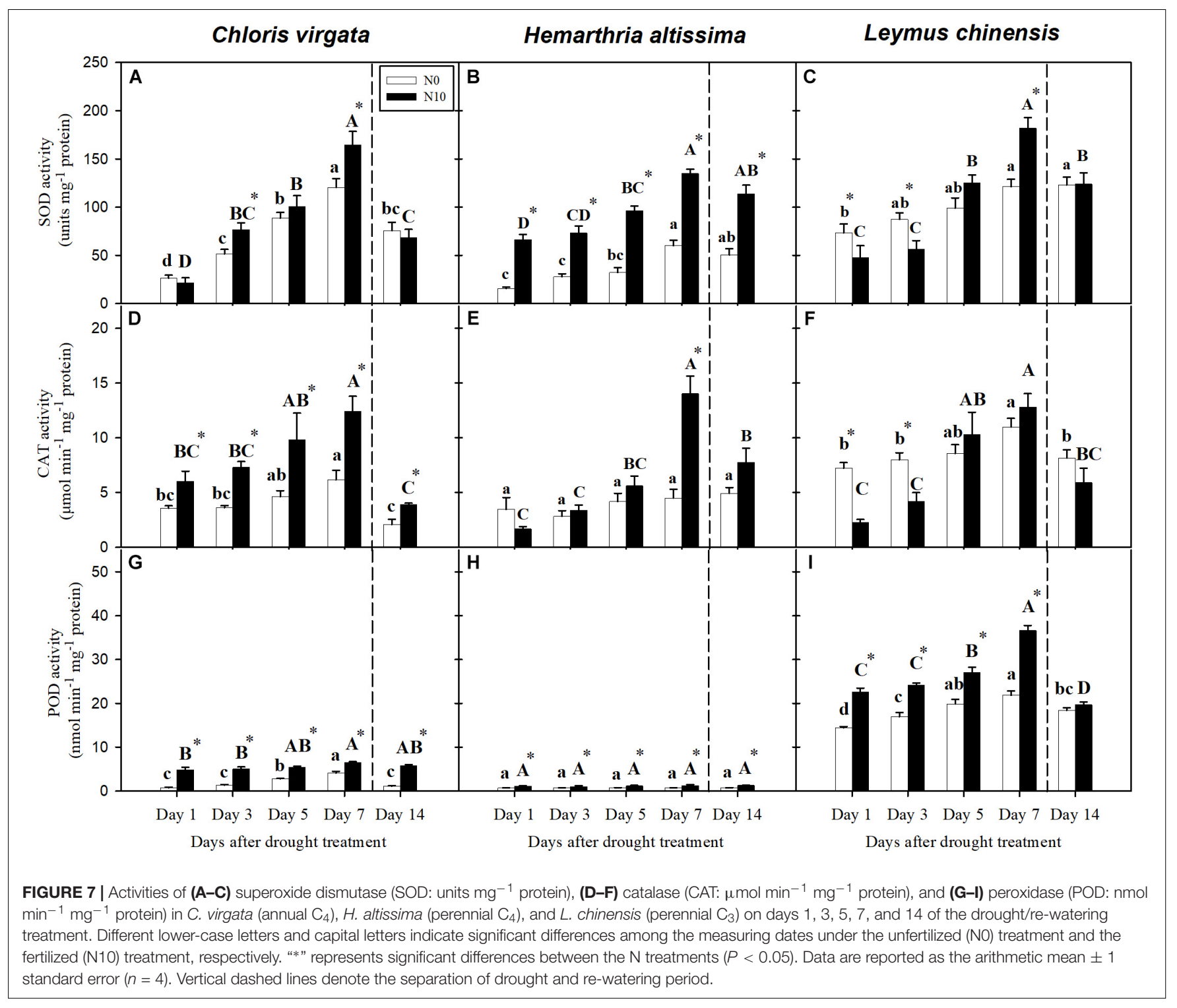

in which starch content decreased both in the $\mathrm{C}_{3}$ and $\mathrm{C}_{4}$ grasses and sugar content increased in the $\mathrm{C}_{4}$ grasses but not in the $\mathrm{C}_{3}$ grass L. chinensis (Zhong et al., 2017).

The osmotic compounds accumulated or synthesized can include anions and cations, amino acids, methylated quaternary ammonium compounds and hydrophilic proteins (Chaves et al., 2003). Certain cellular solutes such as proline and sugars can provide protection of macromolecules, and osmotic adjustment can develop during the drought. We note that the change in concentration and osmotic pressure of proline (Table 2 and Figure 6C) and could conclude that proline likely helps protect these species during the drought period in a non-osmotic manner, such as by stabilizing macromolecules (Reddy et al., 2004). The change in sugar concentrations were different between the $\mathrm{C}_{3}$ and $\mathrm{C}_{4}$ grasses (Table 2 and Figure $6 \mathrm{C}$ ). Contrary to the $\mathrm{C}_{4}$ grasses, the decrease of $\pi$ in the fertilized $\mathrm{C}_{3}$ grass (Figure 6C) may be due to respiration rather than accumulation of sugars. These results indicate varying degrees of osmotic adjustment during drought among these species, and that some other compounds contribute to the overall change in $\Psi$ during drought. In future studies, other osmotic compounds should be measured to determine the dominant compound(s) of osmotic adjustment in these species.

Superoxide dismutase (SOD), catalase (CAT), and peroxidase (POD) could reduce progressive oxidative damage and ultimately cell death (Smirnoff, 1998; Dat et al., 2000; Sharma et al., 2012). Consistent with previous studies (Zhang and Kirkham, 1996), we detected differences in antioxidant responses to drought in the $\mathrm{C}_{3}$ and $\mathrm{C}_{4}$ grasses (Figure 5). Presumably these enzymes helped to regulate the excess excitation energy processing within PSII in the absence of endpoint carbon fixation, as indicated by the reductions in $F_{\mathrm{V}} / F_{\mathrm{M}}$. Nitrogen could enhance the carbon fixation capacity of plants, and is one of the main components of amino acids. The $\mathrm{N}$ addition treatment helped upregulate 
the concentrations of proline and sugars and the activities of antioxidant enzymes in both $\mathrm{C}_{3}$ and $\mathrm{C}_{4}$ grasses (Table 2). However, $\mathrm{N}$ addition could not compensate for the decline in photosynthesis induced by the restriction of photosynthetic enzymes, thus reducing photosynthetic resistance to drought. Yet, such restriction of photosynthetic enzymes would obviate higher antioxidant protection as PSII would continue to be oxidized in sunlit leaves. $\mathrm{N}$ addition resulted in greater aboveground biomass, which would likely increase soil water consumption due to increased leaf area and thus transpiration, which resulted in more extreme drought stress (Yahdjian and Sala, 2006; Hu Z. et al., 2010). However, dense canopies can decrease ground-level light availability, thus reducing soil surface temperature and evaporation (Borer et al., 2014). More studies are required for the understanding of $\mathrm{N}$ addition impacts on plant water balance and antioxidant enzyme activity.

Extreme drought could lead to photoinhibition, which induces photo-oxidative damage to the photosynthetic apparatus (Valladares and Pearcy, 2002). Dynamic photoinhibition is a reversible, regulatory process that controls the dissipation of excessive light energy for photoprotection by the xanthophyll cycle pool (Demmig-Adams and Adams III, 2000). By contrast, chronic photoinhibition stems from photodamage involving the turnover of proteins D1 and D2 under drought conditions (Werner et al., 2002). Chlorophyll fluorescence measurements (i.e., $\left.F_{\mathrm{V}} / F_{\mathrm{M}}\right)$ indicate the maximal efficiency of excitation energy capture by "open" PSII reaction centers; decreases in this parameter indicates plants are subjected to photoinhibition during water stress (Souza et al., 2004). The values for $F_{V} / F_{M}$ were lower for all grass species at the end of drought period (Figure 4), consistent with numerous other studies (Ogaya and Peñuelas, 2003; Hu L. et al., 2010; Cardoso et al., 2018). All three species exhibited a two- to sixfold increase in SOD, CAT, and POD enzyme activity. SOD and CAT participate in the de-excitation of the energized xanthophyll cycle (Müller-Moulé et al., 2002), and their increases are consistent with the decreases in $F_{\mathrm{V}} / F_{\mathrm{M}}$ during drought. $F_{\mathrm{V}} / F_{\mathrm{M}}$ was significantly lower in the fertilized compared to the unfertilized plants. This suggests greater damage to PSII oxygen-evolving core complexes and reaction centers caused possibly by a lesser ability to adjust thermal dissipation processes in the unfertilized plants (Colom and Vazzana, 2003). For all grass species, the opposite trends between PLA and PRA in the unfertilized and fertilized plants (Figures 3A,B) reflect to a certain degree dynamic $(P L A)$ and chronic (PRA) impacts of drought. These are likely due to different photosynthetic limitations and different degrees of damage to PSII at the end of the drought period, which could result in the differences in both time and degree of recovery during the subsequent re-watering period (Galmés et al., 2007b; Hu L. et al., 2010).

\section{Resilience of Photosynthesis After Re-watering}

Analyzing resistance and resilience by assessing photosynthetic limitations during the drought and re-watering periods was an effective method for determining the sensitivity of the
$\mathrm{C}_{3}$ and $\mathrm{C}_{4}$ grasses to changes in soil water availability. While many studies have addressed different aspects of photosynthetic limitations only during drought, the resilience limitations after re-watering have received considerably less attention (Galmés et al., 2007b). The re-watering treatment induced upregulation of photosynthesis, but the patterns of upregulation were different between the $\mathrm{C}_{3}$ and $\mathrm{C}_{4}$ grasses. Moreover, the extent and rate of recovery was influenced by the $\mathrm{N}$ addition treatment (Figures 2A-C, 3B,C), which depended on both the severity of drought stress and the capacity for recovery of stomatal opening and photosynthetic biochemistry (Galmés et al., 2007b; Hu L. et al., 2010; Ripley et al., 2010; Shi et al., 2018). The resilience of photosynthesis suggests that water stress did not irreversibly damage the light reactions of PSII, and that any damage was repaired during re-watering, promoting the recovery of photosynthesis (Flexas et al., 2004). The observed upregulation of $F_{\mathrm{V}} / F_{\mathrm{M}}$ following re-watering is consistent with this observation (Figures $4 \mathbf{A}-\mathbf{C}$ ), although we note that recovery was not fully complete by day 14 .

Normally, the recovery of photosynthesis after a moderate water stress is rapid and almost complete (Flexas et al., 2006). By contrast, after severe water stress, the upregulation of photosynthesis is progressive, slow (taking several days to weeks), and usually incomplete (Miyashita et al., 2005). The unfertilized $\mathrm{C}_{4}$ grasses had higher $\mathrm{R}_{\mathrm{ML}}$ and lower $P R A$ relative to the unfertilized $\mathrm{C}_{3}$ grass (Figures 3B, 4D-F). Similar results have also been reported in other studies (Ripley et al., 2007, 2010). These results suggest the operation of alternative or additional mechanisms of photosynthetic inhibition and constraints on upregulation of photosynthesis in the $\mathrm{C}_{4}$ grasses (Figures $\mathbf{2 A - C}$ ). Quick recovery from drought stress for $\mathrm{C}_{3}$ grasses may enhance their competitiveness relative to $\mathrm{C}_{4}$ grasses under the scenarios of altered precipitation regimes. For all three grass species, lower soil content were observed in the fertilized pots by comparison to the unfertilized pots (Figures 1A-C), which resulted in lower $P R A$ (Figure 3B). Also, photosynthetic recovery was co-limited by incomplete stomatal opening (Figures 2D-F) and upregulation of metabolic pathways in the fertilized pots (Table 1). Photosynthetic $\mathrm{CO}_{2}$ assimilation for the fertilized $\mathrm{C}_{3}$ and $\mathrm{C}_{4}$ grasses did not fully recover at the end of the re-watering period (Figure 3A). Recovery rate of photosynthesis was greater in the fertilized H. altissima and L. chinensis plants, but not in the fertilized C. virgata plants (Figure 3C), which could be attributed to more water stress injury caused by greater plant transpiration for C. virgata (Figure 2G and Supplementary Figure 4). The different resilience between $C$. virgata and $H$. altissima may be attributed to subtype associated different drought sensitivity, $C$. virgata and $H$. altissima belong to PEP-carboxykinase enzyme (PEPCK) subtype and NADP-malic enzyme (NADPME) subtype, respectively (Pyankov et al., 2010; Luo et al., 2013). Compared with NAD-malic enzyme (NAD-ME) subtype, NADP-ME, and PEPCK subtypes are less drought resistant under the drought environment (Hattersley, 1992). However, there is no research about the drought sensitivity between PEPCK and NADP-ME subtypes and consistent conclusion about the sensitivity difference among the $\mathrm{C}_{4}$ subtypes (Ellis et al., 1980; Hattersley, 1992; Taub, 2000). Moreover, drought sensitivity may 
differ among subfamilies independent of $\mathrm{C}_{4}$ subtype. Taub (2000) reported that Panicoideae is more resistant to drought compare to the Chloridoideae. Eventually, C. virgata and H. altissima are differed in life form, and have different root system, which may also attribute to the detected different drought sensitivity (Peek et al., 2005). Greater recovery rate of photosynthesis could be because $\mathrm{N}$ addition increased leaf $\mathrm{N}$ content and enhanced $\mathrm{N}$ allocation to Rubisco, which is the primary $\mathrm{CO}_{2}$ fixation enzyme and has a low rate of catalysis (Makino et al., 1992; Makino, 2011; Fleischer et al., 2013).

The recovery of photosynthesis was constrained by both stomatal and metabolic limitations (Figures 2D-F and Table 1). Galmés et al. (2007b) found that recovery of $g_{\mathrm{m}}$ is the most important factor limiting photosynthetic upregulation after severe water stress. The limited resilience of hydraulic conductivity in the leaf is the apparent cause of the reduced stomatal conductance after re-watering (Galmés et al., 2007b), and it has been shown that aquaporins also play an important role in the regulation of dynamic changes in the variable hydraulic conductance in the leaves (Cochard et al., 2007). Recently, Johnson et al. (2018) showed that the water conducting system could be damaged (via xylem cavitation) by drought, and leaves could not recover hydraulic conductivity after rehydration. Prolonged drought would cause more severe damage in the fertilized plants, which could make recovery more difficult after rehydration. The role of $g_{\mathrm{m}}$ in explaining photosynthetic limitation and the extent of xylem embolism within these grass leaves needs to be further investigated.

Despite the experiment was carefully designed and results are promising, we recognize the limitations of using pot experiments to predict the sensitivity of photosynthesis in $C_{3}$ versus $C_{4}$ grass species in response to climate change (Passioura, 2006; Poorter et al., 2012). Firstly, the temperature was not controlled in this study, which may impact the water and $\mathrm{N}$ responses of $\mathrm{C}_{3}$ and $\mathrm{C}_{4}$ species (Niu et al., 2008a). Secondly, the plant nutrition, water relations, or other interactions in the rhizosphere may be difficult to relate to plants growing in the field, even if field soils are used (Pankhurst et al., 2002). Finally, pot size could influence the structure and physiology of roots, which further limit the plant photosynthesis and growth (Falik et al., 2005; Passioura, 2006). Future research needs to be conducted in natural plant communities with multiple $\mathrm{C}_{3}$ and $\mathrm{C}_{4}$ species coexisting and concurrent with manipulations of more environmental factors.

\section{CONCLUSION}

Compared to the $\mathrm{C}_{3}$ grass L. chinensis, the $\mathrm{C}_{4}$ grasses C. virgata, and $H$. altissima had greater carbon assimilation rates under moderate drought conditions, but this advantage was lost at the end of the drought treatment, especially for the fertilized grasses. In the initial stage of the drought period, $\mathrm{N}$ addition enhanced the activities of photosynthetic enzymes and reduced stomatal limitation of all grass species, which resulted in higher photosynthetic $\mathrm{CO}_{2}$ assimilation in the fertilized grasses. However, $\mathrm{N}$ addition caused a strong increase in biomass and resulted in more severe drought stress in the later period of the drought treatment, leading to a change in the dominant photosynthetic limitation and greater downregulation of photosynthetic rates. Nitrogen addition caused upregulation of the concentrations of proline and sugars and the activities of antioxidant enzymes, and the reduction in photosynthetic enzyme activity during drought did not fully recover after rehydration. $\mathrm{N}$ addition resulted in greater PLA under the drought conditions and lower PRA at the end of the re-watering treatment. However, $\mathrm{N}$ addition resulted in higher $\mathrm{N}$ content in the leaves, which led to faster recovery of $A$ upon re-watering. The findings of this study indicate that the effect of $\mathrm{N}$ addition on photosynthesis during drought was asymmetric, especially in the plants with a low PNUE such as our $\mathrm{C}_{3}$ grass species. In order to understand the explicit roles of water and nutrients in regulating the temporal niche separation among plant functional types differing in photosynthetic pathway, future manipulative research needs to be conducted in natural plant communities with multiple coexisting $\mathrm{C}_{3}$ and $\mathrm{C}_{4}$ species.

\section{DATA AVAILABILITY}

All datasets generated for this study are included in the manuscript and/or the Supplementary Files.

\section{AUTHOR CONTRIBUTIONS}

SZ, WS, and J-YM conceived and designed the experiments. SZ, $\mathrm{BM}$, and YX conducted the experiments. WS and SZ analyzed the data and wrote the manuscript. ML provided several suggestions and critically reviewed the manuscript. All authors read and approved the manuscript.

\section{FUNDING}

This research was supported by the National Key Basic Research Program of China (2015CB150800), the National Natural Science Foundation of China (31570470, 41671207, and 31270445), the Fundamental Research Funds for the Central Universities (2412018ZD010), the Main Service Project of Characteristic Institute of Chinese Academy of Sciences (TSS-2015-014-FW-5-1), and the 9th Thousand Talents Program of China (2013).

\section{ACKNOWLEDGMENTS}

We thank Yunbo Wang for providing valuable comments and suggestions on early drafts. We are also grateful to Hugh A. L. Henry for revising the whole manuscript.

\section{SUPPLEMENTARY MATERIAL}

The Supplementary Material for this article can be found online at: https://www.frontiersin.org/articles/10.3389/fpls.2019.00815/ full\#supplementary-material 


\section{REFERENCES}

Anderson, C. M., and Kohorn, B. D. (2001). Inactivation of Arabidopsis SIP1 leads to reduced levels of sugars and drought tolerance. J. Plant Physiol. 158, 1215-1219. doi: 10.1078/s0176-1617(04)70149-2

Ashraf, M., and Foolad, M. R. (2007). Roles of glycine betaine and proline in improving plant abiotic stress resistance. Environ. Exper. Bot. 59, 206-216. doi: 10.1016/j.envexpbot.2005.12.006

Bates, L. S., Waldren, R. P., and Teare, I. D. (1973). Rapid determination of free proline for water-stress studies. Plant Soil 39, 205-207. doi: 10.1007/bf00018060

Bernacchi, C. J., Pimentel, C., and Long, S. P. (2003). In vivo temperature response functions of parameters required to model RuBP-limited photosynthesis. Plant Cell Environ. 26, 1419-1430. doi: 10.1046/j.0016-8025.2003.01050.x

Bernacchi, C. J., Singsaas, E. L., Pimentel, C., Portis, A. R. Jr., and Long, S. P. (2001). Improved temperature response functions for models of Rubiscolimited photosynthesis. Plant Cell Environ. 24, 253-259. doi: 10.1046/j.13653040.2001.00668.x

Borer, E. T., Seabloom, E. W., Gruner, D. S., Harpole, W. S., Hillebrand, H., Lind, E. M., et al. (2014). Herbivores and nutrients control grassland plant diversity via light limitation. Nature 508, 517-520. doi: 10.1038/nature13144

Bradford, M. M. (1976). A rapid and sensitive method for the quantitation of microgram quantities of protein utilizing the principle of protein-dye binding. Anal. Biochem. 72, 248-254. doi: 10.1006/abio.1976.9999

Cardoso, A. A., Brodribb, T. J., Lucani, C. J., Damatta, F. M., and Mcadam, S. A. (2018). Coordinated plasticity maintains hydraulic safety in sunflower leaves. Plant Cell Environ. 41, 2567-2576. doi: 10.1111/pce.13335

Chance, B., and Maehly, A. C. (1955). [136] Assay of catalases and peroxidases. Methods Enzymol. 2, 764-775. doi: 10.1016/s0076-6879(55)02300-8

Chaves, M. M. (1991). Effects of water deficits on carbon assimilation. J. Exper. Bot. 42, 1-16. doi: 10.1093/jxb/42.1.1

Chaves, M. M., Maroco, J. P., and Pereira, J. S. (2003). Understanding plant responses to drought-from genes to the whole plant. Funct. Plant Biol. 30, 239-264. doi: 10.1071/FP02076

Chowdhury, S. R., and Choudhuri, M. A. (1985). Hydrogen peroxide metabolism as an index of water stress tolerance in jute. Physiol. Plant. 65, 476-480. doi: 10.1111/j.1399-3054.1985.tb08676.x

Cochard, H., Venisse, J. S., Barigah, T. S., Brunel, N., Herbette, S., Guilliot, A., et al. (2007). Putative role of aquaporins in variable hydraulic conductance of leaves in response to light. Plant Physiol. 143, 122-133. doi: 10.1104/pp.106.090092

Collatz, G. J., Ribas-Carbo, M., and Berry, J. A. (1992). Coupled photosynthesisstomatal conductance model for leaves of $\mathrm{C}_{4}$ plants. Funct. Plant Biol. 19, 519-538. doi: 10.1071/PP9920519

Colom, M. R., and Vazzana, C. (2003). Photosynthesis and PSII functionality of drought-resistant and drought-sensitive weeping lovegrass plants. Environ. Exp. Bot. 49, 135-144. doi: 10.1016/s0098-8472(02)00065-5

Cornic, G., Bukhov, N. G., Wiese, C., Bligny, R., and Heber, U. (2000). Flexible coupling between light-dependent electron and vectorial proton transport in illuminated leaves of $\mathrm{C}_{3}$ plants. Role of photosystem I-dependent proton pumping. Planta 210, 468-477. doi: 10.1007/pl00008154

Dat, J., Vandenabeele, S., Vranová, E., Van Montagu, M., Inzé, D., and Van Breusegem, F. (2000). Dual action of the active oxygen species during plant stress responses. Cell. Mol. Life Sci. CMLS 57, 779-795. doi: 10.1007/ s000180050041

Demmig-Adams, B., and Adams III, W. W. (2000). Photosynthesis: harvesting sunlight safely. Nature 403:371. doi: 10.1038/35000315

Ellis, R. P., Vogel, J. C., and Fuls, A. (1980). Photosynthetic pathways and the geographical distribution of grasses in South West Africa/Namibia. S. Afr. J. Sci. 76, 307-314.

Falik, O., Reides, P., Gersani, M., and Novoplansky, A. (2005). Root navigation by self inhibition. Plant Cell Environ. 28, 562-569. doi: 10.1111/j.1365-3040.2005. 01304.x

Fleischer, K., Rebel, K. T., Van Der Molen, M. K., Erisman, J. W., Wassen, M. J., Van Loon, E. E., et al. (2013). The contribution of nitrogen deposition to the photosynthetic capacity of forests. Glob. Biogeochem. Cycles 27, 187-199. doi: 10.1002/gbc.20026

Flexas, J., Bota, J., Loreto, F., Cornic, G., and Sharkey, T. D. (2004). Diffusive and metabolic limitations to photosynthesis under drought and salinity in $\mathrm{C}_{3}$ plants. Plant Biol. 6, 269-279. doi: 10.1055/s-2004-820867
Flexas, J., Ribas-Carbó, M., Bota, J., Galmés, J., Henkle, M., Martínez-Cañellas, S., et al. (2006). Decreased rubisco activity during water stress is not induced by decreased relative water content but related to conditions of low stomatal conductance and chloroplast $\mathrm{CO}_{2}$ concentration. New Phytol. 172, 73-82. doi: 10.1111/j.1469-8137.2006.01794.x

Galmés, J., Medrano, H., and Flexas, J. (2007a). Photosynthesis and photoinhibition in response to drought in a pubescent (var. minor) and a glabrous (var. palaui) variety of Digitalis minor. Environ. Exper. Bot. 60, 105-111. doi: 10.1016/j.envexpbot.2006.08.001

Galmés, J., Medrano, H., and Flexas, J. (2007b). Photosynthetic limitations in response to water stress and recovery in Mediterranean plants with different growth forms. New Phytol. 175, 81-93. doi: 10.1111/j.1469-8137.2007.02087.x

Ghannoum, O., Conroy, J. P., Driscoll, S. P., Paul, M. J., Foyer, C. H., and Lawlor, D. W. (2003). Nonstomatal limitations are responsible for droughtinduced photosynthetic inhibition in four $\mathrm{C}_{4}$ grasses. New Phytol. 159, 599-608. doi: 10.1046/j.1469-8137.2003.00835.x

Giannopolitis, C. N., and Ries, S. K. (1977). Superoxide dismutases: I. Occurrence in higher plants. Plant Physiol. 59, 309-314. doi: 10.1104/pp.59.2.309

Giardi, M. T., Cona, A., Geiken, B., Kučera, T., Masojidek, J., and Mattoo, A. K. (1996). Long-term drought stress induces structural and functional reorganization of photosystem II. Planta 199, 118-125. doi: 10.1007/ bf00196888

Grassi, G., and Magnani, F. (2005). Stomatal, mesophyll conductance and biochemical limitations to photosynthesis as affected by drought and leaf ontogeny in ash and oak trees. Plant Cell Environ. 28, 834-849. doi: 10.1111/ j.1365-3040.2005.01333.x

Hattersley, P. W. (1992). " $\mathrm{C}_{4}$ photosynthetic pathway variation in grasses (Poaceae): its significance for arid and semi-arid lands," in Desertified Grasslands: Their Biology and Management, ed. G. P. Chapman (London: Academic Press), 81-212.

Haxeltine, A., and Prentice, I. C. (1996). BIOME3: an equilibrium terrestrial biosphere model based on ecophysiological constraints, resource availability, and competition among plant functional types. Glob. Biogeochem. Cycles 10, 693-709. doi: 10.1029/96gb02344

Hoerling, M., and Kumar, A. (2003). The perfect ocean for drought. Science 299, 691-694. doi: 10.1126/science.1079053

Hu, L., Wang, Z., and Huang, B. (2010). Diffusion limitations and metabolic factors associated with inhibition and recovery of photosynthesis from drought stress in a $\mathrm{C}_{3}$ perennial grass species. Physiol. Plant. 139, 93-106. doi: 10.1111/j.13993054.2010.01350.x

Hu, Z., Yu, G., Fan, J., Zhong, H., Wang, S., and Li, S. (2010). Precipitation-use efficiency along a 4500-km grassland transect. Glob. Ecol. Biogeogr. 19, 842-851. doi: 10.1111/j.1466-8238.2010.00564.x

Ibrahim, D. G., Gilbert, M. E., Ripley, B. S., and Osborne, C. P. (2008). Seasonal differences in photosynthesis between the $\mathrm{C}_{3}$ and $\mathrm{C}_{4}$ subspecies of Alloteropsis semialata are offset by frost and drought. Plant Cell Environ. 31, 1038-1050. doi: 10.1111/j.1365-3040.2008.01815.x

IPCC (2013). Climate Change 2013: The Physical Science Basis Contribution of Working Group I to the Fifth Assessment Report of the Intergovernmental Panel on Climate Change. Cambridge: Cambridge University Press.

Jia, Y., and Gray, V. M. (2004). Influence of phosphorus and nitrogen on photosynthetic parameters and growth in Vicia faba L. Photosynthetica 42, 535-542. doi: 10.1007/s11099-005-0010-5

Johnson, K. M., Jordan, G. J., and Brodribb, T. J. (2018). Wheat leaves embolized by water stress do not recover function upon rewatering. Plant Cell Environ. 41, 2704-2714. doi: 10.1111/pce.13397

Karl, T. R., Knight, R. W., and Plummer, N. (1995). Trends in high-frequency climate variability in the twentieth century. Nature 377, 217-220. doi: 10.1038/ $377217 \mathrm{a} 0$

Knapp, A. K., Beier, C., Briske, D. D., Classen, A. T., Luo, Y., Reichstein, M., et al. (2008). Consequences of more extreme precipitation regimes for terrestrial ecosystems. AIBS Bull. 58, 811-821. doi: 10.1641/b58 0908

Knapp, A. K., Hoover, D. L., Wilcox, K. R., Avolio, M. L., Koerner, S. E., La Pierre, K. J., et al. (2015). Characterizing differences in precipitation regimes of extreme wet and dry years: implications for climate change experiments. Glob. Change Biol. 21, 2624-2633. doi: 10.1111/gcb. 12888 
Lawlor, D. W. (2002). Limitation to photosynthesis in water-stressed leaves: stomata vs. metabolism and the role of ATP. Ann. Bot. 89, 871-885. doi: 10. $1093 / \mathrm{aob} / \mathrm{mcf} 110$

Lawlor, D. W., and Cornic, G. (2002). Photosynthetic carbon assimilation and associated metabolism in relation to water deficits in higher plants. Plant Cell Environ. 25, 275-294. doi: 10.1046/j.0016-8025.2001.00814.x

Liu, X., Duan, L., Mo, J., Du, E., Shen, J., Lu, X., et al. (2011). Nitrogen deposition and its ecological impact in China: an overview. Environ. Pollut. 159, 22512264. doi: 10.1016/j.envpol.2010.08.002

Liu, X., Zhang, Y., Han, W., Tang, A., Shen, J., Cui, Z., et al. (2013). Enhanced nitrogen deposition over China. Nature 494, 459-462. doi: 10.1038/nature11917

Loik, M. E., and Nobel, P. S. (1991). Water relations and mucopolysaccharide increases for a winter hardy cactus during acclimation to subzero temperatures. Oecologia 88, 340-346. doi: 10.1007/bf00317576

Long, S. P. (1999). “Environmental responses," in $C_{4}$ Plant Biology, eds R. F. Sage and R. K. Monson (London: Academic Press), 215-249.

Luo, Q., Takano, T., and Liu, S. (2013). Proteomic analysis of Chloris virgata leaves under carbonate stress. Cell Biol. Biophys. 1, 1-7. doi: 10.5376/cbb.2013.02.0001

Makino, A. (2011). Photosynthesis, grain yield, and nitrogen utilization in rice and wheat. Plant Physiol. 155, 125-129. doi: 10.1104/pp.110.165076

Makino, A., Sakashita, H., Hidema, J., Mae, T., Ojima, K., and Osmond, B. (1992). Distinctive responses of ribulose-1,5-bisphosphate carboxylase and carbonic anhydrase in wheat leaves to nitrogen nutrition and their possible relationships to $\mathrm{CO}_{2}$-transfer resistance. Plant Physiol. 100, 1737-1743. doi: 10.1104/pp.100. 4.1737

Mencuccini, M., and Hölttä, T. (2010). The significance of phloem transport for the speed with which canopy photosynthesisand belowground respiration are linked. New Phytol. 185, 189-203. doi: 10.1111/j.1469-8137.2009.03050.x

Miyashita, K., Tanakamaru, S., Maitani, T., and Kimura, K. (2005). Recovery responses of photosynthesis, transpiration, and stomatal conductance in kidney bean following drought stress. Environ. Exper. Bot. 53, 205-214. doi: 10.1016/j. envexpbot.2004.03.015

Morgan, J. M. (1984). Osmoregulation and water stress in higher plants. Annu. Rev. Plant Physiol. 35, 299-319. doi: 10.1146/annurev.pp.35.060184.001503

Müller-Moulé, P., Conklin, P. L., and Niyogi, K. K. (2002). Ascorbate deficiency can limit violaxanthin de-epoxidase activity in vivo. Plant Physiol. 128, 970-977. doi: 10.1104/pp.010924

Nelson, D. P., and Kiesow, L. A. (1972). Enthalpy of decomposition of hydrogen peroxide by catalase at $25^{\circ} \mathrm{C}$ (with molar extinction coefficients of $\mathrm{H}_{2} \mathrm{O}_{2}$ solutions in the UV). Anal. Biochem. 49, 474-478. doi: 10.1016/0003-2697(72) 90451-4

Niu, S., Liu, W., and Wan, S. (2008a). Different growth responses of $\mathrm{C}_{3}$ and $\mathrm{C}_{4}$ grasses to seasonal water and nitrogen regimes and competition in a pot experiment. J. Exp. Bot. 59, 1431-1439. doi: 10.1093/jxb/ern051

Niu, S., Wu, M., Han, Y., Xia, J., Li, L., and Wan, S. (2008b). Water-mediated responses of ecosystem carbon fluxes to climatic change in a temperate steppe. New Phytol. 177, 209-219.

Niu, S., Yuan, Z., Zhang, Y., Liu, W., Zhang, L., Huang, J., et al. (2005). Photosynthetic responses of $\mathrm{C}_{3}$ and $\mathrm{C}_{4}$ species to seasonal water variability and competition. J. Exp. Bot. 56, 2867-2876. doi: 10.1093/jxb/eri281

Nobel, P. (2001). "Ecophysiology of Opuntia ficus-indica," in FAO Plant Production and Protection Paper (FAO), eds C. Mondragón Jacobo and S. P. érez González (Rome: FAO).

Ogaya, R., and Peñuelas, J. (2003). Comparative field study of Quercus ilex and Phillyrea latifolia: photosynthetic response to experimental drought conditions. Environ. Exp. Bot. 50, 137-148. doi: 10.1016/s0098-8472(03)00019-4

Pankhurst, C. E., Pierret, A., Hawke, B. G., and Kirby, J. M. (2002). Microbiological and chemical properties of soil associated with macropores at different depths in a red-duplex soil in NSW Australia. Plant Soil 238, 11-20. doi: 10.1023/A: 1014289632453

Parry, M. A. J., Andralojc, P. J., Khan, S., Lea, P. J., and Keys, A. J. (2002). Rubisco activity: effects of drought stress. Ann. Bot. 89, 833-839. doi: 10.1093/aob/ $\operatorname{mcf} 103$

Passioura, J. B. (2006). The perils of pot experiments. Funct. Plant Biol. 33, 1075-1079. doi: 10.1071/FP06223

Pearcy, R. W., and Ehleringer, J. (1984). Comparative ecophysiology of $\mathrm{C}_{3}$ and $\mathrm{C}_{4}$ plants. Plant Cell Environ. 7, 1-13. doi: 10.1111/j.1365-3040.1984.tb01194.x
Peek, M. S., Leffler, A. J., Ivans, C. Y., Ryel, R. J., and Caldwell, M. M. (2005). Fine root distribution and persistence under field conditions of three co-occurring Great Basin species of different life form. New Phytol. 165, 171-180. doi: 10. 1111/j.1469-8137.2004.01186.x

Pelloux, J., Jolivet, Y., Fontaine, V., Banvoy, J., and Dizengremel, P. (2001). Changes in Rubisco and Rubisco activase gene expression and polypeptide content in Pinus halepensis M. subjected to ozone and drought. Plant Cell Environ. 24, 123-131. doi: 10.1046/j.1365-3040.2001.00665.x

Peña-Rojas, K., Aranda, X., and Fleck, I. (2004). Stomatal limitation to $\mathrm{CO}_{2}$ assimilation and down-regulation of photosynthesis in Quercus ilex resprouts in response to slowly imposed drought. Tree Physiol. 24, 813-822. doi: 10.1093/ treephys/24.7.813

Poorter, H., Bühler, J., van Dusschoten, D., Climent, J., and Postma, J. A. (2012). Pot size matters: a meta-analysis of the effects of rooting volume on plant growth. Funct. Plant Biol. 39, 839-850. doi: 10.1071/FP12049

Pyankov, V. I., Ziegler, H., Akhani, H., Deigele, C., and Luettge, U. (2010). European plants with $\mathrm{C}_{4}$ photosynthesis: geographical and taxonomic distribution and relations to climate parameters. Bot. J. Linn. Soc. 163, 283-304. doi: 10.1111/j.1095-8339.2010.01062.x

Qu, G., and Guo, J. (2003). The relationship between different plant communities and soil characteristics in Songnen grassland. Acta Pratacult. Sin. 12, 18-22.

Raven, J. A., Wollenweber, B., and Handley, L. L. (1992). A comparison of ammonium and nitrate as nitrogen sources for photolithotrophs. New Phytol. 121, 19-32. doi: 10.1111/j.1469-8137.1992.tb01088.x

Reddy, A. R., Chaitanya, K. V., and Vivekanandan, M. (2004). Drought-induced responses of photosynthesis and antioxidant metabolism in higher plants. J. Plant Physiol. 161, 1189-1202. doi: 10.1016/j.jplph.2004.01.013

Reichstein, M., Bahn, M., Ciais, P., Frank, D., Mahecha, M. D., Seneviratne, S. I., et al. (2013). Climate extremes and the carbon cycle. Nature 500, 287-295. doi: $10.1038 /$ nature 12350

Ripley, B. S., Frole, K., and Gilbert, M. (2010). Differences in drought sensitivities and photosynthetic limitations between co-occurring $\mathrm{C}_{3}$ and $\mathrm{C}_{4}$ (NADP-ME) Panicoid grasses. Ann. Bot. 105, 493-503. doi: 10.1093/aob/mcp307

Ripley, B. S., Gilbert, M. E., Ibrahim, D. G., and Osborne, C. P. (2007). Drought constraints on $\mathrm{C}_{4}$ photosynthesis: stomatal and metabolic limitations in $\mathrm{C}_{3}$ and $\mathrm{C}_{4}$ subspecies of Alloteropsis semialata. J. Exp. Bot. 58, 1351-1363. doi: 10.1093/jxb/erl302

Sharma, P., Jha, A. B., Dubey, R. S., and Pessarakli, M. (2012). Reactive oxygen species, oxidative damage, and antioxidative defense mechanism in plants under stressful conditions. J. Bot. 2012:26. doi: 10.1155/2012/217037

Shi, B., Wang, Y., Meng, B., Zhong, S., and Sun, W. (2018). Effects of nitrogen addition on the drought susceptibility of the Leymus chinensis meadow ecosystem vary with drought duration. Front. Plant Sci. 9:254. doi: 10.3389/fpls. 2018.00254

Smirnoff, N. (1998). Plant resistance to environmental stress. Curr. Opin. Biotechnol. 9, 214-219. doi: 10.1016/s0958-1669(98)80118-3

Smith, M. D. (2011). An ecological perspective on extreme climatic events: a synthetic definition and framework to guide future research. J. Ecol. 99, 656663. doi: 10.1111/j.1365-2745.2011.01798.x

Souza, R. P., Machado, E. C., Silva, J. A. B., Lagôa, A. M. M. A., and Silveira, J. A. G. (2004). Photosynthetic gas exchange, chlorophyll fluorescence and some associated metabolic changes in cowpea (Vigna unguiculata) during water stress and recovery. Environ. Exp. Bot. 51, 45-56. doi: 10.1016/s0098-8472(03)00 $059-5$

Still, C. J., Berry, J. A., Collatz, G. J., and Defries, R. S. (2003). Global distribution of $\mathrm{C}_{3}$ and $\mathrm{C}_{4}$ vegetation: carbon cycle implications. Glob. Biogeochem. Cycles 17, 6.1-6.14. doi: 10.1029/2001GB001807

Taiz, L., and Zeiger, E. (1991). "Phloem translocation," in Plant Physiology, eds E. Beard-Brady, L. Donohoe, and J. Funston (Redwood City, CA: The Benjamin/Cummings Publishing Company, Inc.).

Taub, D. R. (2000). Climate and the US distribution of $\mathrm{C}_{4}$ grass subfamilies and decarboxylation variants of $\mathrm{C}_{4}$ photosynthesis. Am. J. Bot. 87, 1211-1215. doi: $10.2307 / 2656659$

Taylor, S. H., Ripley, B. S., Martin, T., De-Wet, L. A., Woodward, F. I., and Osborne, C. P. (2014). Physiological advantages of $\mathrm{C}_{4}$ grasses in the field: a comparative experiment demonstrating the importance of drought. Glob. Change Biol. 20, 1992-2003. doi: $10.1111 /$ gcb.12498 
Taylor, S. H., Ripley, B. S., Woodward, F. I., and Osborne, C. P. (2011). Drought limitation of photosynthesis differs between $C_{3}$ and $C_{4}$ grass species in a comparative experiment. Plant Cell Environ. 34, 65-75. doi: 10.1111/j.13653040.2010.02226.x

Valladares, F., and Pearcy, R. W. (2002). Drought can be more critical in the shade than in the sun: a field study of carbon gain and photo-inhibition in a Californian shrub during a dry El Niño year. Plant Cell Environ. 25, 749-759. doi: 10.1046/j.1365-3040.2002.00856.x

Von Caemmerer, S. (2000). Biochemical Models of Leaf Photosynthesis. Clayton, VIC: CSIRO publishing.

Wang, Y., Jiang, Q., Yang, Z., Sun, W., and Wang, D. (2015). Effects of water and nitrogen addition on ecosystem carbon exchange in a meadow steppe. PLoS One 10:e0127695. doi: 10.1371/journal.pone.0127695

Wang, Y., Meng, B., Zhong, S., Wang, D., Ma, J., and Sun, W. (2018). Aboveground biomass and root/shoot ratio regulated drought susceptibility of ecosystem carbon exchange in a meadow steppe. Plant Soil 432, 259-272. doi: 10.1007/ s11104-018-3790-7

Werner, C., Correia, O., and Beyschlag, W. (2002). Characteristic patterns of chronic and dynamic photoinhibition of different functional groups in a Mediterranean ecosystem. Funct. Plant Biol. 29, 999-1011. doi: 10.1071/ PP01143

Xia, J., and Wan, S. (2008). Global response patterns of terrestrial plant species to nitrogen addition. New Phytol. 179, 428-439. doi: 10.1111/j.1469-8137.2008. 02488.x

Xu, X., Sherry, R. A., Niu, S., Li, D., and Luo, Y. (2013). Net primary productivity and rain-use efficiency as affected by warming, altered precipitation, and clipping in a mixed-grass prairie. Global Change Biol. 19, 2753-2764. doi: 10. $1111 /$ gcb. 12248

Yahdjian, L., and Sala, O. E. (2006). Vegetation structure constrains primary production response to water availability in the Patagonian steppe.
Ecology 87, 952-962. doi: 10.1890/0012-9658(2006)87\%5B952:vscppr\%5D2. 0.co;2

Yuan, Z., Liu, W., Niu, S., and Wan, S. (2007). Plant nitrogen dynamics and nitrogen-use strategies under altered nitrogen seasonality and competition. Ann. Bot. 100, 821-830. doi: 10.1093/aob/mcm178

Zhang, J., and Kirkham, M. B. (1996). Antioxidant responses to drought in sunflower and sorghum seedlings. New Phytol. 132, 361-373. doi: 10.1111/j.1469-8137.1996.tb01856.x

Zhao, D., Mackown, C. T., Starks, P. J., and Kindiger, B. K. (2010). Rapid analysis of nonstructural carbohydrate components in grass forage using microplate enzymatic assays. Crop Sci. 50, 1537-1545. doi: 10.2135/cropsci2009.09.0521

Zhong, S., Chai, H., Xu, Y., Li, Y., Ma, J.-Y., and Sun, W. (2017). Drought sensitivity of the carbon isotope composition of leaf dark-respired $\mathrm{CO}_{2}$ in $\mathrm{C}_{3}$ (Leymus chinensis) and $\mathrm{C}_{4}$ (Chloris virgata and Hemarthria altissima) grasses in Northeast China. Front. Plant Sci. 8:1996. doi: 10.3389/fpls.2017.01996

Zhu, K., Chiariello, N. R., Tobeck, T., Fukami, T., and Field, C. B. (2016). Nonlinear, interacting responses to climate limit grassland production under global change. Proc. Natl. Acad. Sci. U.S.A. 113, 10589-10594. doi: 10.1073/ pnas. 1606734113

Conflict of Interest Statement: The authors declare that the research was conducted in the absence of any commercial or financial relationships that could be construed as a potential conflict of interest.

Copyright (c) 2019 Zhong, Xu, Meng, Loik, Ma and Sun. This is an open-access article distributed under the terms of the Creative Commons Attribution License (CC BY). The use, distribution or reproduction in other forums is permitted, provided the original author(s) and the copyright owner(s) are credited and that the original publication in this journal is cited, in accordance with accepted academic practice. No use, distribution or reproduction is permitted which does not comply with these terms. 